Barker Simon (Orcid ID: 0000-0002-3090-1403)

Van Eaton Alexa (Orcid ID: 0000-0001-6646-4594)

Mastin Larry Garver (Orcid ID: 0000-0002-4795-1992)

Wilson Colin (Orcid ID: 0000-0001-7565-0743)

Thompson Mary Anne (Orcid ID: 0000-0002-4093-7055)

Renwick James Arthur (Orcid ID: 0000-0002-9141-2486)

\title{
Modeling ash dispersal from future eruptions of Taupo supervolcano
}

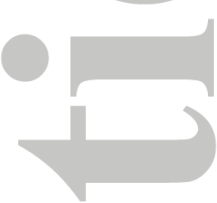

S. J. Barker ${ }^{1,2 *}$, A. R. Van Eaton $^{3}$, L. G. Mastin ${ }^{3}$, C. J. N. Wilson ${ }^{2}$, M. A. Thompson ${ }^{1}$, T. M. Wilson $^{4}$, C. Davis ${ }^{5}$, J. A. Renwick ${ }^{2}$

${ }^{1}$ School of Environment, University of Auckland, Private Bag 92109, Auckland 1142, New Zealand

${ }^{2}$ School of Geography, Environment and Earth Sciences, Victoria University of Wellington, P.O. Box 600, Wellington 6140, New Zealand

${ }^{3}$ U.S. Geological Survey, Cascades Volcano Observatory, Vancouver, Washington 98683, USA

${ }^{4}$ Department of Geological Sciences, University of Canterbury, Private Bag 4800,

Christchurch 8140, New Zealand

${ }^{5}$ Meteorological Service of New Zealand Limited, Wellington, New Zealand

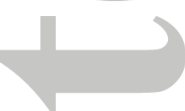

*Corresponding author: Simon Barker (simon.barker@vuw.ac.nz)

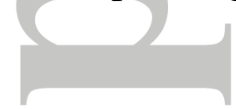

Key Points:

- We model the ashfall distribution from five hypothetical eruption scenarios at Taupo volcano in New Zealand

- Ash3d simulations consider eruptive volume, weather patterns, and umbrella cloud spreading to examine likelihoods of ashfall for major cities

- Synoptic weather classifications are valuable for assessing how changing wind patterns control ash dispersal under different eruption sizes

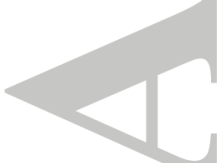

This article has been accepted for publication and undergone full peer review but has not been through the copyediting, typesetting, pagination and proofreading process which may lead to differences between this version and the Version of Record. Please cite this article as doi: 10.1029/2018GC008152 


\section{Abstract}

Hazard analysis at caldera volcanoes is challenging due to the wide range of eruptive and environmental conditions that can plausibly occur during renewed activity. Taupo volcano,

New Zealand, is a frequently active and productive rhyolitic caldera volcano that has hosted the world's youngest known supereruption and numerous smaller explosive events. To assess ashfall hazard from future eruptions, we have simulated atmospheric ash dispersal using the Ash $3 \mathrm{~d}$ model. We consider five eruption scenarios spanning magma volumes of $0.1-500 \mathrm{~km}^{3}$ and investigate the main factors governing ash dispersal in modern atmospheric conditions. Our results are examined in the context of regional synoptic weather patterns (Kidson types) that provide a framework for assessing the variability of ashfall distribution in different wind fields. For the smallest eruptions ( $\sim 0.1 \mathrm{~km}^{3}$ magma), ashfall thicknesses $>1 \mathrm{~cm}$ are largely confined to the central North Island, with dispersal controlled by day-to-day weather and the dominance of westerly winds. With increasing eruptive volume (1-5 $\mathrm{km}^{3}$ magma), ashfall thicknesses $>1 \mathrm{~cm}$ would likely reach major population centers throughout the North Island. Dispersal is less dependent on weather patterns as the formation of a radially-expanding umbrella cloud forces ash upwind or crosswind, although strong stratospheric winds significantly restrict umbrella spreading. For large eruptions (50-500 $\mathrm{km}^{3}$ magma), powerful expansion of the umbrella cloud results in widespread ashfall at damaging thicknesses $(>10$ $\mathrm{cm}$ ) across most of the North Island and top of the South Island. Synoptic climatology may prove a useful additional technique for long-term hazard planning at caldera volcanoes. 


\section{Introduction}

A major challenge in volcanology is forecasting the impacts of future eruptive activity at long-dormant volcanoes where there is geological evidence for catastrophic, large-scale explosive eruptions. The largest of these, known as supereruptions ( $>450 \mathrm{~km}^{3}$ of magma), will have global-scale impacts on the climate and environment (Self, 2006). However, even among caldera volcanoes that have produced supereruptions, like Taupo in New Zealand, there is great diversity in the young eruptive record, with smaller events being much more common (Wilson, 1993). The same situation is broadly true for numerous other caldera volcanoes, including Long Valley (Hildreth, 2004), Campi Flegrei (Di Vito et al., 1999), Yellowstone (Christiansen, 2001; Lowenstern et al., 2006; Christiansen et al., 2007), Aira (Aramaki,1984), and Santorini (Druitt et al., 1999; Parks et al., 2012). The wide range of eruption sizes from caldera volcanoes makes their hazard assessment inherently problematic as future activity could potentially generate a range of hazards (e.g. ashfall, pyroclastic flows, climate impacts), with variable consequences depending on eruption style and magnitude (Self, 2006; Thompson et al., 2015; De Natale et al., 2017). Fall deposits from buoyant plumes are one of the most common and widespread hazards of explosive activity, and are also the most amenable to modelling and forecasting (Folch, 2012). Assessing ashfall hazards from caldera volcanoes requires careful consideration of eruption behavior and weather patterns to identify the main controls driving ash dispersal and deposition.

Taupo caldera volcano is located in the central North Island of New Zealand. It hosted the youngest supereruption on Earth, the $\sim 25.4$ ka Oruanui eruption, which produced $>530$ $\mathrm{km}^{3}$ of magma (or dense-rock equivalent, DRE: Wilson, 2001; Van Eaton and Wilson, 2013; Vandergoes et al., 2013) (Figure 1a). At least 28 smaller explosive eruptions have occurred since then, with eruptive volumes spanning 3-4 orders of magnitude (Figure 1b) (Wilson, 1993). The largest and most recent explosive eruption devastated a large portion of the North Island around $232 \mathrm{AD}$ (Wilson and Walker, 1985; Hogg et al., 2012) (Figure 2a). Variations in erupted magma compositions over the past 12,000 years, the inferred vent locations, and the range of magma storage depths imply that the modern day magmatic system has rebuilt to a substantial size and is capable of generating bodies of eruptible magma on timescales of years to decades (Barker et al., 2015, 2016). Furthermore, minor unrest episodes have occurred roughly once per decade since 1870 (Potter et al., 2015) and geophysical evidence of unrest in 1982-1983 has been linked to the emplacement and 'dewatering' of magma (Smith et al., 2007). However, studies of the geological record show that eruption volumes have no 
clear relationship to the duration of repose (quiet stages) at the volcano (Wilson, 1993;

Stirling and Wilson, 2002) (Figure 2b, c). Furthermore, tectonic stress, mafic recharge, and the state of the silicic magma system all have demonstrable influences on the timing and volume of past eruptions from Taupo, so it is challenging to forecast future activity (Rowland et al., 2010; Allan et al., 2012; Barker et al., 2016; Wilson, 2017).

The economic and social impacts caused by explosive eruptions have increased greatly over the past few decades, due to factors such as increasing population densities, urbanization, and dependence on air travel. For example, Icelandic eruptions over the past decade (e.g., Eyjafjallajökull 2010, Grímsvötn 2011 and Bardarbunga 2014-15) had significant global economic impacts through flights disruption (Langmann et al., 2012). Similarly, large silicic eruptions in southern Chile had widespread, severe and long-lasting impacts on local agriculture, critical infrastructure and tourism, as well as disruptions to travel overseas (Wilson et al., 2011; Craig et al., 2016; Stewart et al., 2016). Even the relatively small explosive eruptions of Ruapehu in 1995-96 cost the New Zealand economy NZ\$130 million due to disruption and damage to local lifelines, industries, and tourism (Cronin et al., 1998; Johnston et al., 2000; Wilson et al., 2012). These case studies highlight the importance of developing a better understanding of the wide range of uncertain hazards and risks posed by future activity at Taupo volcano, and suggest that ashfall, in particular, could have significant impacts locally, as well as far-reaching effects nationally and regionally throughout the southwest Pacific.

To better constrain our understanding of potential ashfall hazard from Taupo volcano, we adopt a scenario-based approach to assess the hazard from a set of five specific, plausible eruption conditions (e.g. Costa et al., 2009; Davies et al., 2015; Biass et al., 2017), as demonstrated by Taupo's geological record. These scenarios cover both ends of the spectrum in terms of statistical likelihood-including the higher probability, smaller eruptions and lower probability (but higher impact) super-eruptions (see Section 2.1). We combine current understanding of Taupo's volcanic and magmatic history with numerical simulations of ash dispersal from buoyant plumes. By combining thousands of model simulations with a modern understanding of weather patterns in New Zealand (Kidson, 2000), we calculate the likelihood of ashfall across New Zealand and investigate the effects of variable eruption size and atmospheric dynamics on ash dispersal. These first order estimates of the ashfall hazard associated with small-, medium-, large-, and super-sized eruptions from Taupo contribute tangible and quantifiable thresholds for application in risk management planning and impact modeling. 


\section{Modeling strategy and scope}

We use Ash3d, a finite-volume Eulerian model for volcanic ash transport and deposition (Schwaiger et al., 2012; Mastin et al., 2014), to simulate ashfall deposits from a future hypothetical eruption of Taupo volcano. We employ a range of plausible eruption sizes by defining five scenarios (Section 2.1) and running 1,000 simulations per scenario to capture the variability of ash dispersal in modern atmospheric circulation patterns. Each of the 1,000 runs uses a different wind field to account for changing weather patterns (Section 2.2). We endeavored to simplify the simulations as much as possible while still accounting for some of the key factors influencing ash dispersal. For example, we do not include the effects of atmospheric rainfall on ash removal, and assume that $100 \%$ of the erupted mass rises buoyantly into the atmosphere, rather than traveling along the ground as pyroclastic density currents (PDCs). Furthermore, we assume a single, well-tested grain size distribution for all the runs, which accounts for aggregation in a simplified way by grouping the fine ash into coarser size bins (Mastin et al., 2016; Section 2.1; Table 3). These simplifying assumptions are discussed in more detail in Section 4.4.

By simplifying some of the source parameters, we were able to investigate other physical processes in greater detail (e.g., the role of eruption power versus wind speed). The Ash3d model accounts for the horizontal spreading of an umbrella cloud, which can dominate ash transport during high-intensity eruptions (Costa et al., 2013; Mastin et al., 2014). Ash3d simulates ash transport by dividing up the atmosphere into a three-dimensional grid of cells and calculates the mass flux of ash through each cell according to advection by the wind and gravitational settling. The fall velocities of particles are determined by their shape, size and density (Schwaiger et al., 2012; Mastin et al., 2014) using the method of Wilson and Huang (1979). To represent the source term for our smallest eruption scenario $\left(0.1 \mathrm{~km}^{3}\right.$ magma), we use a version of Ash3d that simply places ash in a column of nodes above the volcano without an umbrella cloud (Mastin et al., 2016) (Figure 3a). In this case, the column height represents the maximum height of the plume, and the vertical distribution of mass is assigned using an equation from Suzuki (1983) (eqn 1, Table 1). The variable $k$ controls the mass distribution in the plume (Suzuki, 1983). We use $k=8$ for simulations of the smallest eruption scenario without an umbrella cloud, which places $50 \%$ of the mass in the uppermost $20 \%$ of the column. 
Overshooting tops of larger eruptions can greatly exceed $20 \mathrm{~km}$ (e.g., $40 \mathrm{~km}$ or more at Pinatubo: Holasek et al., 1996), but most of the ash is actually transported within the much lower umbrella cloud (Fero et al., 2009; Suzuki et al., 2016). Ash in the overshooting top collapses gravitationally into the umbrella cloud rather than being advected horizontally in the ambient wind, making umbrella-cloud height more influential than total column height in controlling ash dispersal (Mastin et al., 2014). Therefore, for the larger erupted volumes (>0.1 $\mathrm{km}^{3} \mathrm{DRE}$ ), we simulate an umbrella cloud in the following way (Table 1, Figure 3b):

1. Ash is placed in a column of nodes above the volcano extending from the vent to the specified base of the umbrella cloud and in a $3 \times 3$ matrix of source nodes extending from the base to the top of the umbrella cloud $\left(H_{u}\right)$. Ash is placed in the the nodes extending from the vent only up to $H_{u}$ (not the overshooting cloud top $H_{T}$ ). A value of $k=12$ results in a mass distribution concentrated in a narrower interval compared to $\mathrm{k}=8$, with $50 \%$ of the mass concentrated in the uppermost $15 \%$ of the distance from vent to cloud top. No source nodes exist above the top of the umbrella.

2. At each time step, Ash3d calculates the radius of the umbrella cloud $R$ with time $t$ using equations (2) and (3) in Table 1. Within the cloud, Ash3d adds the umbrella velocity field to the ambient wind field, with radial flow determined by equation (4) in Table 1. The radial flow field simulates the spread of ash within the gravity current forming the umbrella cloud.

\subsection{Eruption Scenarios}

We have defined five eruption scenarios that aim to capture the plausible range of future eruption sizes from Taupo volcano (Figure 1; Table 2). The scenarios are motivated by two considerations. First, Taupo's eruptive volumes through the Holocene have varied from $<0.01$ $\mathrm{km}^{3}$ to $\sim 35 \mathrm{~km}^{3}$ magma (Figure $1 \mathrm{~b}$ ). The smallest eruptions were likely accompanied by effusive lava dome formation, often accompanying or following explosive eruptions (Figure 2b) (Wilson, 1993). For this study we model the explosive activity only, and place our smallest event (Scenario 1) at $0.1 \mathrm{~km}^{3}$ magma, of which there are $\sim 11$ Holocene examples (Table 2). To account for larger events we adopt size ranges from the geological record using $1 \mathrm{~km}^{3}, 5 \mathrm{~km}^{3}$ and $50 \mathrm{~km}^{3}$ magma (Figure 1b). Secondly, we define the maximum credible 
event as a $500 \mathrm{~km}^{3}$ supereruption (Scenario 5, Table 2), emphasizing its extremely low probability (Stirling and Wilson, 2002; Hurst and Smith, 2004, 2010: Table 2). This eruptive volume is based on a recent geochemical study by Barker et al. (2015), which suggested that a substantial volume of partially molten material may be present beneath Taupo (up to 1000 $\mathrm{km}^{3}$ of crystal mush). This is a first-order estimate, in need of confirmation by geophysical observations, but the findings suggest that the present-day Taupo magmatic system is hypothetically capable of a very large eruption. Although supereruptions are rare compared to the smaller events, even at Taupo volcano, it is important to understand the impact of these low probability, very high impact eruptions to develop strategies for mitigation and recovery (Self, 2006). Due to the wide range of eruptive volumes across the five scenarios, we set up three different model domains for the simulations (Figure 4), with a higher resolution nodal spacing $\left(0.25^{\circ}\right)$ for the smaller eruptions of $0.1 \mathrm{~km}^{3}$ and $1 \mathrm{~km}^{3}$ magma (Table 2).

Eruption source parameters are defined using a combination of Taupo's geologic record, analogous eruptions and empirical relationships. Field data from Taupo indicate that most of the eruptions have been continuous and occurred over periods of hours to tens of hours (Wilson, 1993), with the exception of a few examples such as the 232 AD eruption (Houghton et al., 2010). For the smallest eruption, Scenario $1\left(0.1 \mathrm{~km}^{3}\right)$, we use a duration of 6 hours, resulting in a mass eruption rate (MER) of $\sim 1 \times 10^{7} \mathrm{~kg} / \mathrm{s}$ and a plume reaching $15 \mathrm{~km}$ height (Mastin et al., 2009). For the larger eruptions, which include the umbrella module, we use combinations of umbrella height and MER consistent with historic observations (Table 2). In particular, we assume an umbrella height of $15 \mathrm{~km}$ above sea level for Scenario 2 (1 $\mathrm{km}^{3} \mathrm{DRE}$ ), and $20 \mathrm{~km}$ for all of the larger eruptions. These plume heights are within the lower limits of those calculated from Taupo isopleth data (Carey and Sparks, 1986; Wilson, 1993), and are reasonable when compared to modern analogues such as Pinatubo (Fero et al., 2009; Suzuki et al., 2016). Scenario 4 uses an eruption rate based on the 1815 Tambora eruption, where most of the erupted volume $\left(50 \mathrm{~km}^{3} \mathrm{DRE}\right)$ was produced over 24 hours (Self et al., 1984; Sigurdsson and Carey, 1989; Oppenheimer, 2003). For the Scenario 5 supereruption (500 $\mathrm{km}^{3}$ DRE), we have used the $760 \mathrm{ka}$ Bishop Tuff as an analogue, which is inferred to have mostly erupted over 90 hours (Wilson and Hildreth, 1997). We note that both Tambora and the Bishop Tuff produced voluminous pyroclastic flows, which are not explicitly included in our modeling (see Section 4.4 for discussion of limitations).

For all our simulations, we use the grain size distribution of Mastin et al. (2016) to capture the transport of a widely-dispersed deposit that underwent ash aggregation (Table 3). Mastin et al. (2016) modified the grainsize distribution from the 1980 eruption of Mount St. 
Helens (after Durant et al., 2009) to consolidate all of the fine ash ( $<63$ microns) into aggregates (Table 3). The size and density of the aggregates were systematically tuned to fit the distal deposits of four diverse eruptions, including Mount St. Helens 1980, Redoubt 2009, Mount Spurr 1992, and Ruapehu 1996 (Mastin et al., 2016). This is a reasonable option for representing the fine-grained, aggregated plumes that would be expected from Taupo (Walker, 1981a; Van Eaton and Wilson, 2013). To speed up model run-times, all of the particles $>2 \mathrm{~mm}$ are consolidated into the $2 \mathrm{~mm}$ size bin, which has the effect of underestimating the most proximal ashfall thicknesses where coarser particles are deposited (Mastin et al., 2016). Particle densities are based on the componentry and density of Taupo deposits (Houghton et al., 2010) (Table 3). Final deposit thickness is estimated by assuming a deposit density of $1000 \mathrm{~kg} / \mathrm{m}^{3}$ (Schwaiger et al., 2012). We do not take into account the effects of rainfall or wet deposition, which can significantly increase ash deposit loading (Macedonio and Costa, 2012)

\subsection{Meteorological data}

New Zealand's maritime climate in the Southern Pacific Ocean leads to complex surface weather patterns that change over relatively short timescales (Coulter, 1975; Sturman and Tapper, 2008). A synoptic-climatological classification was carried out for the New Zealand region by Kidson (2000) who defined 12 atmospheric circulation types (Figure 5a). They are based on cluster analysis of 12-hourly, $1000 \mathrm{hPa}$ height fields using data from NCEP/NCAR Reanalysis 1 (referred to hereafter as Reanalysis-1) back to 1948 (Kalnay et al., 1996). Each Kidson type typically occurs for 1-2 days on average and only some types show seasonal variability (Kidson, 2000; Renwick, 2011) (Figure 5b). Kidson types are divided into three main weather regimes as determined by the position of low and high pressure systems around New Zealand (Figure 5a) (Renwick, 2011):

1) Trough regime $(\mathrm{T}, \mathrm{SW}, \mathrm{TNW}, \mathrm{TSW})$ - an unsettled, low pressure region centered over New Zealand or towards the east, resulting in winds out of the NW or SW, reduced temperatures, and increased precipitation.

2) Zonal regime $(\mathrm{H}, \mathrm{HNW}, \mathrm{W})$ - a high pressure system centered over New Zealand or to the NW, resulting in winds out of the west (westerlies) and drier conditions in the North Island. 
3) Blocking regime (HSE, HE, NE, HW, R) — a high pressure system to the south of New Zealand, resulting in weaker but more variable winds (depending on the position of the high), wetter conditions in the NE of New Zealand and drier conditions in the SE,

To initialize the background weather inputs for Ash3d simulations, we use the Reanalysis 1 dataset, which are provided at $2.5^{\circ}$ intervals, with 17 vertical pressure levels up to $\sim 34 \mathrm{~km}$ above sea level at 6 hourly time resolution. Higher resolution data from the European ERA-Interim dataset ( $1^{\circ}$ intervals, 60 vertical levels, up to $\sim 64 \mathrm{~km}$ limit) were included in sensitivity studies, but showed little difference compared to Reanalysis-1 (supporting information Figures S1 to S3). Reanalysis-1 has the benefit of having the greatest historical coverage back to 1949 , allowing broader representation of the weather patterns and El Niño Southern Oscillation (ENSO) cycles that can significantly affect New Zealand's atmospheric wind fields and the dominant Kidson types (Jiang et al., 2006; Renwick, 2011).

For each eruption scenario outlined in Table 2, we completed 1,000 Ash3d model simulations that randomly sampled different dates and times in the Reanalysis-1 weather dataset between 1948 and 2016. Each individual run was then assigned a percentage of each Kidson weather regime that occurred during the simulation from the updated database of Kidson (2000), based on 6 hourly sampling across the time period of ashfall transport, up to 8 hours after the end of eruption (once $>99 \%$ of ash was deposited).

\section{Results}

Results from selected Ash3d simulations highlight the effects of increasing eruption intensity and day-to-day weather patterns on ash dispersal (Figures 6 and 7). For the smallest eruption volume of $0.1 \mathrm{~km}^{3}$ magma (Scenario 1: Figure $6 \mathrm{a}, \mathrm{d}, \mathrm{h}$ ), there is little upwind deposition, particularly during strong westerly winds, which tend to dominate the central North Island (Figure 6d, h; supporting information Figures S4 to S8). For the eruptions in scenarios 2 (1 $\mathrm{km}^{3}$ magma) and 3 ( $5 \mathrm{~km}^{3}$ magma), a higher eruption rate leads to the development and radial expansion of an umbrella cloud, and more ash is carried upwind. This is particularly true in light winds, such as those experienced during zonal or blocking weather regimes (e.g. Figure $6 b, c)$. Strong westerlies carry the majority of ash offshore (Figure 6e, f); however, larger eruptions show a notably broader cross-wind deposition due to the effects of an outwardlyexpanding umbrella cloud and increased ash emissions. For example, when the erupted 
volume increases from 0.1 to $5 \mathrm{~km}^{3}$ DRE, ashfall thicknesses $>0.1 \mathrm{~mm}$ expand their crosswind coverage from 130 to $330 \mathrm{~km}$ on the east coast of the North Island between Napier and Gisborne (Figure 6d-f). For the largest eruptions considered here in Scenario $4\left(50 \mathrm{~km}^{3}\right)$ and Scenario 5 $\left(500 \mathrm{~km}^{3}\right)$, significantly more ash is deposited both upwind and crosswind in all examples shown (Figure 7). Strong winds do still skew these ash deposits, however, even at the high eruption rates assumed for those events $\left(\sim 10^{9} \mathrm{~kg} / \mathrm{s}\right.$; Figure $\left.7 \mathrm{c}-\mathrm{d}\right)$. In many cases, transitional weather patterns result in deposit maps that show bilobate or complex distributions (Figure 6h-j, Figure 7e-f). On an individual basis, each model simulation and its resulting ashfall deposit map is highly sensitive to the local wind conditions at the time of eruption.

To address this variability, all 1,000 simulations per scenario were combined to generate probability maps, showing the likelihood of exceeding a given ashfall thickness. Contours show $60 \%, 30 \%$ and $10 \%$ probability, and the $1 \%$ limit (black dashed line) (Figures 8 and 9). In Scenario $1\left(0.1 \mathrm{~km}^{3}\right)$, deposits $>1 \mathrm{~cm}$ thickness are mostly confined to proximal locations ( $<100 \mathrm{~km}$ from vent) in the central North Island and only major population centers located $200-300 \mathrm{~km}$ from vent fall within the $1 \%$ probability of receiving $>1 \mathrm{~cm}$ of ashfall (Figure $8 \mathrm{a}$ ). Probability contours of $>1 \mathrm{~mm}$ ashfall for Scenario 1 are strongly skewed to the east, highlighting the influence of dominant westerly winds in the central North Island (supporting information Figures S4 to S8). Major towns to the northeast and southeast of Taupo fall into the 10-30\% probability range for receiving $>1 \mathrm{~mm}$ of ashfall (Figure $8 \mathrm{~b}$ ). In Scenario $2\left(1 \mathrm{~km}^{3}\right)$, probability contours become less ellipsoidal as a result of increasing cross-wind and up-wind deposition (Figure 8c,d). In this scenario, the 60\% probability contour for receiving $>1 \mathrm{~cm}$ of ashfall covers a much wider area across the eastern central North Island out towards the cities of Napier and Gisborne on the east coast (Figure 8c). Auckland falls within the $10 \%$ probability contour for $>1 \mathrm{~mm}$ of ashfall and all major population centers across the North Island fall within the $1 \%$ limit (Figure 8d). In Scenario 3 $\left(5 \mathrm{~km}^{3}\right)$, all towns in the eastern North Island fall within the $60 \%$ probability contour of receiving $>1 \mathrm{~mm}$ of ashfall and all other population centers in the North Island have significant probabilities (>10\%) of at least this much ashfall (Figure 8e,f). For the largest eruptions considered here, probability contours are more circular in shape and begin to cover parts of the South Island for deposits of $10 \mathrm{~cm}$ and $1 \mathrm{~cm}$ thickness (Figure 9). In Scenario 4 $\left(50 \mathrm{~km}^{3}\right)$ the whole central and eastern North Island has a $>60 \%$ probability of receiving $>10$ $\mathrm{cm}$ of ashfall, with Auckland and Wellington at $~ 30 \%$ and $10 \%$ probability, respectively (Figure 9a). In Scenario $5\left(500 \mathrm{~km}^{3}\right)$ the entire North Island and Pacific Ocean out to the 
Chatham Islands is enclosed within the $60 \%$ contour at $10 \mathrm{~cm}$ thickness and in the South Island, Christchurch falls on the $30 \%$ probability contour (Figure 9c). For comparison with field data from previous eruptions of Taupo volcano, the $10 \mathrm{~cm}$ isopach from the total fall deposits (all 10 eruptive phases) from the Oruanui supereruption covers a broadly similar total area and shape to the $60 \%$ probability contour, although it is more shifted to the southeast (Wilson, 2001).

Hazard curves for major population centers in the North Island show the distribution of probable ash accumulation thicknesses alongside four typical damage thresholds $(5,20$, 100 , and $300 \mathrm{~mm}$ ) from Jenkins et al. (2015) (Figure 10). Due to the dominant westerly winds, Napier has the highest probability of $>0.1 \mathrm{~mm}$ ashfall with $\sim 50 \%$ probability for Scenario 1, $\sim 95 \%$ for Scenario 2 and $>99 \%$ for all larger eruptions (Figure 10). Possible thicknesses that occur in Napier increase drastically between eruption scenarios: 0.1-10 mm (Scenario 1), up to $50 \mathrm{~mm}$ (Scenario 2), 10-100 mm (Scenario 3), 100-1000 mm (Scenario 4) and 1000-5000 mm (Scenario 5). To the north of Taupo, Tauranga has a probability of ashfall $>0.1 \mathrm{~mm}$ of $\sim 20 \%$ for Scenario 1, 55\% for Scenario 2, $25 \%$ for Scenario 3 and $>99 \%$ for scenarios 4 and 5 . Notably, there is a significant shift in the shape of the probability-thickness curve for Tauranga between Scenario 3 and 4, with a $<10 \%$ probability of ash thickness $>100 \mathrm{~mm}$ in Scenario 3 versus $\sim 80 \%$ in Scenario 4 (Figure 10c-d). Similar shifts in the probability curve occur for Hamilton, which has $<30 \%$ probability of ashfall $>10$ mm for Scenario 3, compared to $>80 \%$ for Scenario 4. New Plymouth, west of Taupo, has lower probabilities of ashfall than Auckland for Scenarios 1-3 (Figure 10a-c), but then higher probabilities than Auckland at any given thickness for Scenarios 4 (Figure 10d) and 5 (Figure 10e). Auckland and Wellington have the lowest probabilities of ashfall for the major population centers, being located $\sim 250 \mathrm{~km}$ northwest and $\sim 300 \mathrm{~km}$ southwest from Taupo volcano, respectively. Significant ashfall $(>10 \mathrm{~mm})$ fall in these locations at lower probabilities ( $<20-30 \%$ ) for Scenarios 1-3, but these probabilities increase to $50-60 \%$ for Scenario 4 and $>100 \mathrm{~mm}$ of ashfall occurs at $>95 \%$ probabilities in Scenario 5.

Calculated arrival times shown in Table 4 indicate how long it takes for ash to start accumulating on the ground after the start of eruption for some of the major population centers. Average travel times vary from 1 to $\sim 16$ hours depending on city location and eruption size. A notable observation from Table 4 is that all major centers, apart from Napier, show an increase in average travel times from $0.1 \mathrm{~km}^{3}$ (Scenario 1) to $5 \mathrm{~km}^{3}$ eruptions (Scenario 3). In some cities like Auckland, Hamilton and New Plymouth, there is 50-100\% increase in arrival times from Scenarios 1 to 3 . However, there is also greater variability with 
larger eruption sizes, indicating a much wider spread in the simulation individual arrival times. Between the $5 \mathrm{~km}^{3}$ eruptions (Scenario 3) and the $50 \mathrm{~km}^{3}$ (Scenario 4) and $500 \mathrm{~km}^{3}$ eruptions (Scenario 5), average travel times to all centers, including Napier, decrease back to similar or lower values than that estimated for the smaller eruptions, but with high variability for distal locations.

\section{Discussion}

Our discussion focuses on identifying the key factors that control ashfall deposition from Taupo volcano across the five eruption scenarios considered. We compare the model results with evidence from the geological record and examine some limitations of the approach before considering implications for ashfall hazards from calderas.

\subsection{Role of the umbrella cloud}

During explosive volcanic eruptions, there is a distinction between lower-intensity events that generate weak plumes bent-over by the wind (e.g., Carey and Sparks, 1986; Bonadonna and Phillips, 2003) and higher-intensity eruptions that produce laterally-spreading umbrella clouds (e.g., Woods and Kienle, 1994; Sparks et al., 1997; Baines and Sparks, 2005). The conditions controlling this transition have been studied in a number of papers (e.g., Degruyter and Bonadonna, 2012; Aubry et al., 2017). The distinction is important for ashfall modeling because the development of an umbrella cloud will change ash dispersal characteristics, especially upwind or crosswind (e.g. Costa et al., 2013; Mastin et al., 2014). In this study we have assumed that all our eruption scenarios producing $>0.1 \mathrm{~km}^{3}$ magma generate umbrella clouds owing to their associated high eruption rates $\left(>5 \times 10^{7} \mathrm{~kg} / \mathrm{s}\right)$. The assumption that larger-volume eruptions tend to be associated with higher eruption rates is generally supported by historical observations (Carey and Sigurdsson, 1989; Mastin et al., 2009).

For Scenario $1\left(0.1 \mathrm{~km}^{3}\right.$ eruption), the eruption rate of $1 \times 10^{7} \mathrm{~kg} / \mathrm{s}$ means that it borders the threshold for umbrella cloud formation. Recent global eruptions in this size range include the 2014 Kelud eruption in Indonesia (Hargie et al., 2019; Maeno et al., 2019) and the 2015 Calbuco eruption in Chile (Van Eaton et al., 2016), which both produced umbrella clouds. For Calbuco, the umbrella cloud did spread upwind to a distance of $\sim 50 \mathrm{~km}$ from satellite observations, but left no obvious impact on the distribution of ashfall (Van Eaton et 
al., 2016). As a sensitivity study, we ran Scenario 1 with and without the umbrella cloud, using 1,000 simulations with identical weather inputs to compare the overall effect on the probability maps (Figure 11). Results show that at $1 \mathrm{~cm}$ thickness, the $10 \%$ and $30 \%$ contours cover similar areas, but the total area covered by the $1 \%$ contour is significantly greater for the probability map without the umbrella cloud, reflecting the relatively narrow and directional dispersion of individual simulations (Figure $11 \mathrm{a}, \mathrm{c}$ ). There is little overall effect on the total area covered by the $10 \%$ probability contour at $1 \mathrm{~mm}$ ash thickness, but the region covered by the $10 \%$ contour is shifted to the west (Figure $11 \mathrm{~b}, \mathrm{~d}$ ). The total areas of the $30 \%$ and $60 \%$ probability contours at $1 \mathrm{~mm}$ ash thickness increase significantly, by $\sim 50 \%$ and $\sim 100 \%$, respectively, indicating that the umbrella cloud results in more widespread dispersal (more area covered). Despite this observation, deposits from historically mapped eruptions of $0.1 \mathrm{~km}^{3}$ or less have been reproduced accurately without including umbrellacloud growth in the modeling, using both Ash3d (e.g. Mastin et al., 2016) and other models (e.g. Folch et al., 2010). Our results suggest that it is acceptable to model these smaller eruptions without umbrella growth due to its relatively minor role in ash dispersal, but acknowledge that the subtle effects could be important to be aware of for future work.

\subsubsection{Eruption intensity vs. wind speed}

Umbrella clouds form when strong volcanic plumes inject ash above the level of neutral buoyancy and the plume spreads out as a gravity-driven intrusion (Woods and Kienle, 1994). At low eruption rates, atmospheric winds dominate ash transport because the umbrella cloud expansion rate is relatively weak (passive regime in the model of Costa et al., 2013: Figure 11). In contrast, at eruption rates associated with the largest explosive eruptions, densitydriven transport can dominate to the point where spreading is insensitive to stratospheric winds (Baines and Sparks, 2005; Costa et al., 2013). The range of MERs covered by our five eruptive scenarios span two orders of magnitude from $\sim 1 \times 10^{7}$ to $\sim 5 \times 10^{9} \mathrm{~kg} / \mathrm{s}$ (Table 2). Therefore we expect density-driven transport to increasingly dictate how much ash is dispersed and deposited upwind and cross-wind in the larger events.

Using the example of Pinatubo 1991, Costa et al. (2013) demonstrated the importance of growth of an umbrella cloud when simulating the evolution of volcanic clouds from large explosive events. Costa et al. (2013) described the density-driven regime to passive-regime transition as a function of the Richardson number $(R i)$, which compares the expansion speed of the cloud's outer margin $u_{R}$ with the mean wind velocity $u_{W}$ at the neutral buoyancy level: 


$$
R i=\left(\frac{u_{R}^{2}}{{u_{W}}^{2}}\right)=\frac{4}{9{u_{W}}^{2}}\left(\frac{\beta \lambda N \dot{V}}{2 \pi}\right)^{2 / 3} t^{-2 / 3}
$$

where $\lambda$ is an umbrella-cloud shape factor (Suzuki \& Koyaguchi, 2009), $N$ is the Brunt-

Väisälä frequency and $\dot{V}$ is the volume flux rate of air, gas and particles into the cloud (as in Table 1). When $R i>1$, the transport mechanism is mainly density-driven, whereas for $R i<$ 0.25 , transport is mostly passive and dictated by wind advection (Costa et al., 2013). The interval $0.25<R i<1$ is considered to be a transitional interval that separates the two different turbulent regimes and degrees of mixing. The timescales characterizing densitydriven transport $\left(t_{b}\right)$ and passive transport $\left(t_{p}\right)$ processes in the plume are given by:

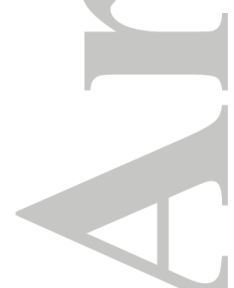

$$
\begin{aligned}
t_{b} & =\frac{4 \lambda N \dot{V}}{9 \pi u_{W}{ }^{3}} \\
t_{p} & =\frac{32 \lambda N \dot{V}}{9 \pi u_{W}{ }^{3}}
\end{aligned}
$$

Combining the timescales calculated for Equations 6 and 7 with Equation 2 (Table 1), Costa et al. (2013) demonstrated how the dominant transport mechanism varies as a function of eruption rate and distance $(R)$ of the umbrella cloud front from source (Figure 12). For comparison, we show the five eruption scenarios used here on the transport mechanism regime diagram from Costa et al. (2013) where $u_{W}=15 \mathrm{~m} / \mathrm{s}$ and $30 \mathrm{~m} / \mathrm{s}, \lambda=0.2$ and $N=$ 0.02 , to estimate the typical distance from vent where the density-driven regime dominates $(R i>1)$ versus the transitional $(0.25<R i<1)$ and passive regime $(R i<0.25)$ across the different MERs. Figure 12 highlights two key points about the role of umbrella cloud dynamics in controlling ash dispersal:

1. The distance from vent where the density-driven regime dominates increases over two orders of magnitude with increasing MER across the five scenarios at a fixed value of $u_{W}=15 \mathrm{~m} / \mathrm{s}$ (Figure 12a,b). For the smaller eruptions $\left(0.1\right.$ and $\left.1 \mathrm{~km}^{3}\right)$, density-driven transport in the cloud is dominant only $20 \mathrm{~km}$ for Scenario 1 and $90 \mathrm{~km}$ for Scenario 2, beyond which the ambient winds start to dominate the dispersal. For Scenario 3, density-driven transport is dominant to over $\sim 200 \mathrm{~km}$ from vent and the transitional zone stretches out to $\sim 700 \mathrm{~km}$. At the highest MERs in scenarios 4 and 5, densitydriven transport is dominant over distances of $>1000 \mathrm{~km}$.

2. Doubling the stratospheric winds from $15 \mathrm{~m} / \mathrm{s}$ to $30 \mathrm{~m} / \mathrm{s}$ reduces the calculated 
distance of the density-driven regime field $(R i>1)$ by a factor of $\sim 4$ (Figure 12c). For Scenario 3, wind speeds of $30 \mathrm{~m} / \mathrm{s}$ reduce the density-driven transport field down to $<50 \mathrm{~km}$ from vent and the transitional regime down to $<200 \mathrm{~km}$, indicating that transport is dominantly passive (Figure 12d). At one extreme, stratospheric wind speeds at 16-24 km above Taupo on average are $\sim 15 \mathrm{~m} / \mathrm{s}$, but in winter average $\sim 30$ $\mathrm{m} / \mathrm{s}$ and commonly reach $40 \mathrm{~m} / \mathrm{s}$ and occasionally $55 \mathrm{~m} / \mathrm{s}$ (supporting information Figures S4 to S8). Such wind speeds would impact the ashfall dispersal pattern of even the highest intensity eruptions (MER $\sim 10^{9} \mathrm{~kg} / \mathrm{s}$, similar in magnitude to scenario 4 and 5).

The role of the umbrella cloud and its ability to transport ash up- or cross-wind is therefore not only a function of eruption rate, but also of stratospheric wind speeds (Costa et al., 2013; Marti et al., 2016). This raises the question: which is the dominant factor in these Taupo examples? We suggest that the effect of stratospheric wind speeds on ash dispersal is reflected by the wide variety of final deposition maps generated by our modeling, even at high MERs. For example, Scenario 3 ( $5 \mathrm{~km}^{3}$ eruption) has a MER similar to the 1991 Pinatubo eruption (e.g. Fero et al., 2009), but sustained over a 24 hour period. Despite this high MER, the final deposit maps from this scenario commonly show skewed ash distribution with very little upwind deposition in simulations with strong winds (e.g. Figure $7 f, j$ ). Although these simulation maps are of final deposit thickness (and not the position of the ash cloud), stratospheric wind strength will dictate the up-wind reach of the umbrella cloud from which ash particles start falling, to be subsequently influenced by lower-level tropospheric winds. Ambient winds can therefore be seen as playing two main roles in governing ash dispersal. First, high-level stratospheric winds around the neutral buoyancy level may restrict up-wind umbrella cloud spreading via the density-driven regime (Costa et al., 2013; Figure 12). This interaction is sensitive to eruption intensity and will have a first-order control on up-wind ash dispersal and can affect ash dispersal on the scale of hundreds of kilometers with relatively minor changes in stratospheric wind speed, even for the most powerful eruptions (Figure 12). Second, lower-level tropospheric winds will move ash shedding from the umbrella cloud in the direction of the prevailing, dominantly westerly, winds (supporting information Figures S4 to S8). The distance ash will travel down-wind after falling from the umbrella region is subsequently dependent on several variables including umbrella height, wind speed, particle size, density and shape (Wilson and Huang, 1979).

Umbrella cloud formation and its relationship to eruption intensity must also be 
considered when interpreting average times for ash arrival (Table 4) and probabilitythickness curves (Figure 10). With increasing eruption volume, MER, plume height and umbrella height, average arrival times initially increase between scenarios 1-3 for most main centers and the probability of ashfall steadily increases. Longer arrival times are inferred to reflect that ash has a further vertical distance to travel between scenarios 1 and 3 with the increasing plume height and umbrella cloud formation (Table 2). With increasing eruption size, centers located at further distances from Taupo or in up-wind or cross-wind directions, have a higher overall probability of receiving ashfall (Figure 10) and therefore, more simulations will be included in average arrival calculations for larger eruptions. The wider range of possible travel times is reflected in the substantially higher standard deviations shown in Table 4 for Scenario 3. For scenarios 4 and 5, average travel times decrease substantially across all major centers and the shape of the probability-thickness curves change drastically, especially for areas located in distal locations (Figure 10). We interpret these changes to reflect the increasing radial velocities within the umbrella cloud, which is able to rapidly cover the central North Island. All centers within 200-300 km from vent start receiving ashfall within a few hours and distal locations have a much higher probability of ashfall.

\subsection{The role of weather patterns}

To investigate the effect of different weather regimes on ash dispersal, we assigned each individual simulation with a percentage of the different Kidson types occurring over each 6hr interval of ashfall deposition (Figure 5). As each Kidson type lasts on average for 1-1.5 days (Kidson, 2000), most of the simulations contain a mixture of synoptic classifications, especially for the larger eruptions with longer durations. To isolate the role of distinct weather regimes on ash dispersal, we identified some examples where the ashfall was deposited within a single Kidson type (e.g. Figure 6a-f and Figure 7a-d; supporting information Figures S14 to S18).

Figure 13 shows the cumulative probability $(P c)$ of ash exceeding a given thicknesses, grouped by location and eruption scenario. Thickness data are extracted at each location for different Kidson types from the number of simulations $(n)$ that only experienced $100 \%$ of a given Kidson type and ranked $(X r)$ in descending order such that:

$$
P c=\frac{X r}{n+1}
$$


For example, in a Scenario 2 eruption $\left(1 \mathrm{~km}^{3}\right)$, when Kidson types R, HW and HSE from the blocking regime and type $\mathrm{H}$ from the zonal regime occur there is a much higher probability of ashfall in Auckland $220 \mathrm{~km}$ to the northwest of Taupo (Figure 13a). Ashfall probabilities in Auckland for these weather situations are roughly two to three times higher than the exceedance probability calculated from all 1,000 simulations across the range of observed thicknesses. In contrast, all other Kidson types have a much lower probability or no examples of ashfall occurring in Auckland, especially those from the trough regime (blue colors in Figure 13). Similar results are observed for Tauranga, although some ash may occur at low probability from trough regimes or weather situations from cross-wind deposition due to its closer proximity to Taupo ( $110 \mathrm{~km}$ from vent) (Figure 13b). In contrast, when Kidson types from the trough regime or types NE or HE from the blocking regime occur, there is a higher probability of ashfall in Napier (Figure 13c). However, the probability of ashfall in Napier is still high under most weather conditions for Scenario 2. For Wellington, $\sim 300 \mathrm{~km}$ to the SW of Taupo, only particular Kidson types like NE or HSE from the blocking regime or TSW from the trough regime result in a higher probability of ashfall occurring ( 20-40\%), with all other weather situations having a very low or zero probability of ashfall occurring in this location.

Variations in exceedance probabilities between Kidson types generally decrease for larger eruption sizes, particularly at proximal sites (Figure 13e-h). We interpret these changes with increasing eruption size to result from the increasing role of the umbrella cloud with higher MERs and its ability to push ash up-wind or cross-wind in the stratosphere. However, certain weather conditions associated with strong westerly winds (e.g. Kidson types T, SW, W) still result in a low probability of ashfall occurring at distal locations (<10-20\%), despite the larger eruption size. These findings highlight the complex interplay between the ability of the umbrella cloud to push ash up-wind or cross-wind in the stratosphere and variable weather in the troposphere affecting proximal versus distal ashfall-thickness probability curves.

The observation that particular Kidson synoptic types correspond with a higher probability of ashfall occurrence at certain geographical locations raises three key questions.

1. What weather conditions result in the thickest accumulations in major population centers? 
The wide variation in final ash distribution maps is a function of the wide range of wind conditions that may occur on any given day across the range of eruption sizes considered (Figures 6 and 7). In general, Kidson types associated with light winds over the North Island (such as those experienced during zonal or blocking regimes) result in the highest probability of ashfall at major centers, whereas trough regimes and strong associated westerly winds lead to most of the ash being distributed off to the east and over the Pacific Ocean. Due to most major populations centers being north/west of Taupo, any weather system that generates light southerly winds will result in the highest probability of ashfall in population centers like Tauranga, Hamilton or Auckland (Figure 13). Of particular mention are Kidson types HSE and $\mathrm{H}$ which occur on average about one-quarter of the time, where a large high pressure system is situated close to or over the North Island resulting in light southerly or southwesterly winds. As Kidson type $\mathrm{H}$ transitions to HSE $>60 \%$ of the time as the high pressure system moves across New Zealand (Kidson, 2000), this combination could last several days and result in particularly thick accumulations for longer eruption durations. Kidson types $\mathrm{R}$ and type NE from the blocking regime, associated with a weak low pressure system positioned to the east or west of the North Island, are less common but also associated with higher probabilities of ashfall at key locations (Figure 13).

\section{Is the probability of ashfall at key locations sensitive to seasonal or any other predictable weather drivers?}

When considered on a monthly basis, ashfall probabilities across the range of eruption sizes are generally higher at most major centers between January and March (summer/fall) and lower between July and September (winter/spring) (supporting information Figures S9 to S13). For example, exceedance probabilities of ashfall occurring in Auckland for Scenario 3 $\left(5 \mathrm{~km}^{3}\right)$ are approximately twice as high between January-March $(22 \%$ at $10 \mathrm{~mm}$ and $10 \%$ at $40 \mathrm{~mm}$ ) than July-September $(12 \%$ at $10 \mathrm{~mm}$ and $4 \%$ at $40 \mathrm{~mm})$. We consider that this strong seasonal variability results from two key weather phenomena, or a combination thereof. First, the westerly flow at 16-24 km height is stronger in winter (with wind speeds averaging $~ 30$ $\mathrm{m} / \mathrm{s}$ ) and weaker in summer (to < $10-15 \mathrm{~m} / \mathrm{s}$ : supporting information Figures $\mathrm{S} 4$ to S8; Andrews et al., 1987). Wind strength changes at these heights will affect the umbrella cloud spreading, with weak winds allowing ash to spread in up-wind or cross-wind directions, especially for larger eruptions (Figure 12). Second, at lower levels in the troposphere, blocking regimes are more common in summer months (Figure 5b), which are typically 
associated with lighter and more variable winds and thus higher probabilities of ashfall (Figure 13).

3. Can scenario-based probabilistic ash dispersal models be combined with synoptic climatology as an additional forecasting or planning tool?

Synoptic-climatological classifications (i.e. Kidson types) have proven to be a useful meteorological technique for defining climate and local atmospheric circulation variability over a region which is effectively used as a form of downscaling analysis (Yarnal, 1993). This technique has been successfully used to assess local climate variability, key climate drivers (e.g. Southern Oscillation Index: SOI), climate change impacts and to reconstruct palaeoclimate (Yarnal, 1993; Renwick, 2011; Jiang et al., 2012; Lorrey et al., 2012). We suggest that synoptic climatology may also prove useful as an additional tool for assessing the variability of ashfall hazards (e.g. Hurst and Smith, 2004), particularly in regions like New Zealand where atmospheric circulation is sensitive to multiple climate drivers (e.g. SOI and Southern Annular Mode: SAM). As large-scale climate drivers are typically forecast on a medium (monthly) to long-term (seasonal/yearly) basis

(https://www.pmel.noaa.gov/elnino/sst-and-enso-predictions), ashfall probability maps, such as those developed in this work, could in the future be adjusted to reflect changes in climate drivers as they happen, leading to a dynamic probabilistic hazard assessment. Such an approach would depend on further developing a model to comprehensively predict synoptic types with season (e.g. Jiang et al., 2012) and could be applied to long-term planning and used for communicating the variability of ashfall hazards under specific climate patterns to end-users. For shorter-term planning (e.g. weeks to months during caldera unrest episodes), long range (seasonal) ensemble models could be combined with scenario-based probabilistic hazard maps. This approach would yield more focused hazard projections that incorporate important aspects of atmospheric circulation that are known in the present and predictable on this forecast time scale (e.g. ENSO) to arrive at a 'what if' analysis for a broad range of eruption sizes. Such an approach would provide a first-order hazard assessment prior to more accurate operational dispersal simulations that are widely used by ash advisory groups , where ash fall simulations incorporate high-resolution short range NWP forecasts to provide ash forecasting in response to unrest or ongoing eruptions (e.g. Roebber et al., 2004; Hurst and Davis, 2017). 


\subsection{Comparisons with the geological record}

Taupo volcano has hosted 28 eruptions since the 25.4 ka Oruanui supereruption. Twenty-five of these occurred within the Holocene (past $~ 12 \mathrm{kyr}$ ), when weather patterns were broadly similar to the present-day. Their eruptive volumes ranged over several orders of magnitude (Figure 2), enabling a record of eruptive deposits that allow for comparisons with the simulation results presented here. However, several key factors relating to the size of the eruptions and nature of the deposits limit such comparisons. For smaller eruptions $\left(<1 \mathrm{~km}^{3}\right)$, only proximal records have been documented in isopach maps where thicknesses typically exceed a few cm (Wilson, 1993). Distal records of such events are limited by preservation in New Zealand's heavily vegetated landscape and typically limited to sheltered environments (e.g. peat bogs and lake records), making it challenging to compare broad dispersal characteristics with our model outputs. Further, while isopach maps have been calculated for relevant large events from both Taupo and for other TVZ caldera-forming eruptions (e.g. Wilson, 2001; Lowe et al., 2013), interpretation of ash dispersal for these older eruptions requires caution, given that atmospheric conditions may have been drastically different (e.g. glacial vs. interglacial periods). Considering these limitations, several general inferences can be made about patterns of ash dispersal in the geological record:

1. The dominance of westerly winds. Holocene eruption deposits of variable size have dispersal axes in dominantly northeast to southeast direction from Taupo (Figure 14a). Only three units are southerly dispersed and only one subunit (E1) shows weak dispersal to the west. In addition, several deposits show evidence for changing wind directions during the eruption (e.g. units B, E, G, U, Y), also noted as a common feature in our simulation results with changing weather. For larger eruptions such as the 232 AD Taupo (Unit Y) and the $3.4 \mathrm{ka}$ Waimihia (Unit S) eruptions, isopach maps highlight the strong control of westerly winds (e.g. Rhoades et al., 2002), but also show significant cross-wind dispersal ( $>100 \mathrm{~km}$ ) for thicknesses of $>100 \mathrm{~mm}$ (Figure 14b; Walker, 1981b; Wilson and Walker, 1985). Eruptive deposits from Okataina volcano ( $100 \mathrm{~km}$ to the northeast of Taupo) also reflect the general dominance of westerly winds (Lowe et al., 2013; Thompson et al., 2015). However, light southwesterly or strong southeasterly wind conditions occurred during the $\sim 55 \mathrm{ka}$ Rotoiti eruption and the 1314 AD Kaharoa eruption, respectively, with ash being driven towards the top of the North Island (Newnham et al., 2004; Lowe et al., 2008). 
2. Selected eruptions are recorded in distal and upwind locations. Interpretations of distal records are hampered by a lack of tephra preservation or reliable stratigraphy. However, records of thin ashfall layers from several Holocene Taupo eruptions are preserved in cores from lakes or bogs throughout the North Island, suggesting that they had much wider coverage than implied by published isopach maps (e.g. Pullar et al., 1977; Howorth et al., 1980; Hubbard and Neall, 1980; Lowe, 1988a, b; De Lange and Lowe 1990; Frogatt and Rogers, 1990; Eden et al., 1993; Lowe et al., 1999; Lowe et al., 2013: supporting information Figure S19). For example, tephra from the 232 AD Taupo eruption is preserved as far north as Auckland at thicknesses of up to 10 mm (Gehrels et al., 2006; Zawalna-Geer et al., 2016). In addition, up to five other Taupo-derived tephras are found in Hamilton lakes and bogs and several cryptotephras have been inferred from Auckland lake cores (Lowe et al., 2008; Zawalna-Geer et al., 2016). However, pairing of smaller eruptive units between proximal records and distal records becomes problematic as correlations are based only on radiocarbon dates and certain units (e.g. Unit Q: $0.06 \mathrm{~km}^{3} \mathrm{DRE}$ ) are correlated over much larger areas than would be expected from proximal thickness data and their small estimated eruptive volume (Wilson, 1993; Alloway et al., 1994; supporting information Figure S19). Offshore sediment records to the east of New Zealand also preserve selected Holocene eruptions from Taupo (e.g. units Y, S, C), several eruptions from Okataina and many large older TVZ eruptions (Lowe et al., 2008). Deep offshore sediment records are not reliable indicators of thickness but allow some first-order constraints to be placed on the widespread dispersal of ash from TVZ supereruptions during the Quaternary (Carter et al., 2004; Allan et al., 2008). Such records suggest that ash dispersal may have reached $>300 \mathrm{~km}$ upwind in the $25.4 \mathrm{ka}$ Oruanui supereruption and $>1000 \mathrm{~km}$ in the largest recorded TVZ events such as the 0.35 Ma Whakamaru and 1.0 Ma Kidnappers eruptions (Figure 14d). During such large eruptions, ash dispersal in the atmosphere may last weeks with traces of Oruanui eruption ash found in Antarctica (Dunbar et al., 2017).

\subsection{Assumptions and limitations}

One of the biggest challenges in assessing volcanic hazards is the sheer number of possible scenarios that could arise during any natural event (Sandri et al., 2016). In numerical 
modeling there is a tradeoff between capturing this realistic complexity and providing a meaningful product (e.g. Costa et al., 2009). In this study we have used geologicallymotivated scenarios with simplifying assumptions about the eruption style and weather. Although the approach is limited in terms of quantifying the full scale of possible hazards, it provides a useful quantitative framework for exploring tangible outcomes (e.g. Amer et al., 2013; Davies et al., 2015; Blake et al., 2017; Deligne et al., 2017). Below we examine some of our simplifying assumptions and discuss how they could influence ashfall dispersal in ways not explicitly addressed by our modeling.

\subsubsection{Higher-level ash transport}

Historical observations of volcanic plumes and numerical modeling indicates that even very high-intensity eruptions tend to transport the vast majority of ash in the umbrella region at heights of 15 to $20 \mathrm{~km}$ above sea level (Van Eaton et al., 2012a; Suzuki et al., 2016; Costa et al., 2018). However, there are circumstances under which an umbrella cloud could develop higher than 20 km (Van Eaton et al., 2012a, their Fig. 14). Above the central North Island, a significant atmospheric change occurs between summer and winter where polar stratospheric warming during the spring and summer months weakens the westerly flow and winds may even reverse to become easterly (Andrews et al., 1987). This process is reflected in the Reanalysis-1 data which show easterlies at heights $>24 \mathrm{~km}$ above Taupo from October to March, and westerly flow at lower levels (16-24 km) (supporting information Figure S8). Since our simulations do not include any ash transport above $20 \mathrm{~km}$, they also do not reflect this possible westward transport of ash from a higher-level plume during the summer and spring.

\subsubsection{Eruption duration and vent site}

Our eruptive scenarios assumed a combination of eruption volume, duration, and MER based on empirical relationships from historic eruptions (Mastin et al., 2009). However, it is possible that the same eruptive volume could be produced by a long-lived, weaker plume. In this case, we could expect a number of changes to the ashfall patterns. For one, a longerduration eruption would interact with a greater diversity of wind patterns that would increase the variability of ash dispersal. This would increase the area covered by small amounts of ash and decrease the areas of heavy ashfall (because the same volume would be spread over a 
wider region). There would also be less upwind and crosswind dispersal due to a lower, weaker plume that is more easily directed by the wind. On the contrary, a lower plume could result in more ash being deposited closer to vent. At Taupo, many examples in the geological record also indicate shifting of vent positions (Wilson, 1993; Wilson, 2001). For example, the 232AD Taupo eruption shows evidence for vent migration over a $\sim 10 \mathrm{~km}$ distance (Houghton et al., 2010). As most vent sites are restricted around Lake Taupo to a narrow corridor on the eastern or northern side of the lake (Figure 14a), shifting of vents at this volcano would not significantly change the ash distribution overall, but may result in changing eruption style (e.g. magma interaction with lake water), which is further considered below.

4.4.3 Influences of water and pyroclastic flows

Taupo eruption products have a rich history of magma-water interaction with a long-lived lake system (Walker, 1981a; Wilson, 1993; Van Eaton and Wilson, 2013). Three relevant aspects of water interaction and eruption style are simplified for the purposes of our study:

1. Ash aggregation. Adding moisture to the volcanic plume triggers clumping and aggregation of fine ash particles, leading to heavier fallout near the volcano (Walker, 1981a; Van Eaton et al., 2012b; Van Eaton and Wilson, 2013). This typically produces greater proximal thicknesses and lesser in distal areas compared to an identical 'dry' eruption (Van Eaton et al., 2015). Our simulations account for the dynamics of wet volcanism in a very simplified way, by aggregating the grain size distribution of airborne particles (Section 2.1; Table 3). Many factors influence the initial grain size erupted by a volcano (e.g., Walker,1981a,b; Rose and Durant, 2009, Costa et al., 2016), but ash aggregation occurs to some extent in all volcanic plumes, regardless of composition (Brown et al., 2012). As a simplifying assumption, we have used the well-tested grain size distribution from Mastin et al. (2016), which was determined as a best-fit match to the distal deposits of four diverse eruptions, including the wet, heavily aggregated eruption of Redoubt 2009 in Alaska (Van Eaton et al., 2015). This is the only grain size distribution that has been tested for such diverse eruption styles. Therefore, it provides a reasonable approximation for the large-scale pattern of ashfall. Yet, it is worth noting that the grain size inputs were tuned to distal deposits only (Mastin et al., 2016), and likely underestimate the heaviest fallout of ash aggregates near the volcano. 
2. Rainfall scavenging. Second, we have ignored the effects of rainfall, which is another mechanism to scrub fine ash out of the atmosphere and reduce distal transport. These effects would be most significant in "trough" weather regimes, which bring abundant precipitation over the central and western North Island (Renwick, 2011). Rainfall would cause locally heavy fallout of "mud rain" (Walker, 1981a), and likely decrease the overall extent of ashfall downwind. However, the proportion of ash transported in the upper atmosphere (above precipitating clouds) would not be affected.

3. Pyroclastic flows. Magma-water interaction tends to decrease the stability of the plume, leading to pyroclastic density currents (Koyaguchi and Woods, 1996; Van Eaton et al., 2012a). PDCs are also more likely at higher eruption rates (Koyaguchi and Woods, 1996). For very large eruptions (e.g. scenarios 4 and 5) PDC production could lead to secondary co-ignimbrite plumes that could also significantly contribute to total ashfall (e.g. Marti et al., 2016). Our simplifying assumption of modeling $100 \%$ of the erupted mass as buoyant plumes clearly ignores this issue, as Ash3d cannot explicitly model the portion deposited by ground-hugging currents. A major impact of PDCs would be enhanced deposition near Taupo, and lower-level transport of the elutriated ash. This would lead to overall lighter ashfall in distal areas, such as cities along the coasts.

Taken in sum, all of these physical processes would increase the ash thickness burden in proximal areas near Taupo, and decrease its distal extent. Therefore, we expect that our simulations represent the "most widespread" version of each eruptive scenario and the results help constrain the maximum ashfall burden on distal areas and provide a more conservative minimum for the proximal area in the central North Island.

\section{Conclusions}

Using the Ash3d dispersal model we have simulated ash transport and deposition from Taupo volcano to investigate ashfall dispersal patterns in different wind fields. Using our five eruption scenarios, the following conclusions are drawn:

1. On an individual basis, each simulated ashfall deposit is sensitive to local wind conditions, but model results show consistent changes with increasing eruption size across the five scenarios. This reflects an interaction between the radially-spreading 
umbrella cloud that dominates large eruptions, and highly variable wind conditions in New Zealand's mid-latitude oceanic setting. Our results highlight the importance of considering umbrella-cloud formation when modeling ash dispersal from explosive volcanic eruptions of $>0.1 \mathrm{~km}^{3}$ magma.

2. Small eruptions with low eruption rates (Scenario $1: 0.1 \mathrm{~km}^{3} ; 5 \times 10^{7} \mathrm{~kg} / \mathrm{s}$ ) typically generate narrow dispersal patterns that are dictated by day-to-day weather patterns. New Zealand's dominant westerly winds drive ash predominantly to the east coast of the North Island. Expected thicknesses at major towns in the central-eastern North Island are generally $<1 \mathrm{~cm}$. With increasing eruption size, the formation of an umbrella cloud may push significant amounts of ash upwind and crosswind as the plume becomes less sensitive to the weather conditions due to the increasing role of density-driven dispersal in the plume. The ashfall thickness probability contours become more circular for scenarios 2 and $3\left(1\right.$ and $\left.5 \mathrm{~km}^{3}\right)$, with a greater probability (i.e., $>10 \%)$ of ashfall reaching damaging levels $(10-100 \mathrm{~mm})$, especially for major centers in the central and northeastern regions of the North Island.

3. For the largest eruptions modeled in scenarios 4 and 5 (50 and $500 \mathrm{~km}^{3}$ magma), major damage $(100 \mathrm{~mm})$ or severe structural damage $(>300 \mathrm{~mm})$ can be expected in major towns or cities across the North Island, even as far away as Auckland or Wellington. Such wide dispersal is consistent with geological data from terrestrial and marine records around New Zealand. However, strong stratospheric winds may still play a major role in controlling medium- to long-range dispersal. High stratospheric wind speeds of 30-55 m/s restrict the growth of the umbrella cloud over wide regions, even at the highest eruption rates considered here.

4. Particular surface weather patterns increase the probability of ashfall in different locations, highlighting the dependence of ashfall hazards from Taupo eruptions on dynamic weather. Synoptic weather classifications (Kidson types) are a valuable tool for assessing how changing atmospheric circulation patterns control ash dispersal under different eruption sizes. Kidson types typically associated with light but variable winds, such as those experienced during zonal or blocking regimes, result in the thickest ashfall at major towns and cities in the North Island. As Kidson type frequencies change in response to key climate drivers, it may be possible to generate dynamic climate-dependent hazard maps. Synoptic climatology may prove a useful tool for long-term hazard planning or for hazard assessments at Taupo and other 
global locations where multiple climate drivers interact to generate highly variable but predictable weather patterns.

5. Understanding ashfall hazards at caldera volcanoes like Taupo is inherently difficult because of the wide range of possible eruption sizes and conditions that could plausibly occur. However, by investigating the hazard associated with a wide range of possible eruption scenarios, we have highlighted the key role of the umbrella cloud in ashfall dispersion and deposition, showing which areas of New Zealand are more susceptible to ashfall under different weather patterns and eruption sizes. We highlight the need for future studies to model some of the more complex variations in eruption duration, style (e.g., PDCs), and degree of water interaction, which could significantly affect ash dispersal patterns and their impacts.

\section{Acknowledgments, Samples, and Data}

This project was funded by a New Zealand Earthquake Commission (EQC) biennial grant awarded to SJB (grant number 16/724). We also acknowledge continuing support from the ECLIPSE Program supported by the New Zealand Ministry for Business, Innovation and Employment. Hans Schwaiger, Heather Wright and John Pallister (U.S. Geological Survey), Graham Leonard, Tony Hurst and Natalia Deligne (GNS Science),Iman Soltanzadeh (NZ MetService) and Helen Webster (U.K. Met Office) provided helpful suggestions and discussions during this work. We thank Manuel Nathenson (U.S. Geological Survey) and three anonymous reviewers for helpful comments and suggestions that greatly improved this manuscript and Marie Edmonds for editorial handling. The data and model results used in this paper have been posted as a data repository on the USGS ScienceBase-Catalog and can be found using the following link: https://www.sciencebase.gov/catalog/item/5cdd9ed7e4b029273746367a. Any use of trade, firm, or product names is for descriptive purposes only and does not imply endorsement by the U.S. Government.

\section{References}

Allan, A. S. R., Baker, J. A., Carter, L., \& Wysoczanski, R. J. (2008). Reconstructing the Quaternary evolution of the world's most active silicic volcanic system: insights from an 1.65 Ma deep ocean tephra record sourced from Taupo Volcanic Zone, New Zealand. 
Quaternary Science Reviews, 27, 2341-2360.

https://doi.org/10.1016/j.quascirev.2008.09.003

Allan, A. S. R., Wilson, C. J. N., Millet, M-A., \& Wysoczanski, R. J. (2012). The invisible hand: tectonic triggering and modulation of a rhyolitic supereruption. Geology, 40, 563566. https://doi.org/10.1130/G32969.1

Alloway, B. V., Lowe, D. J., Chan, R. P. K., Eden, D. N., \& Froggatt, P. C. (1994). Stratigraphy and chronology of the Stent tephra, a c. 4000 year old distal silicic tephra from Taupo Volcanic Centre, New Zealand. New Zealand Journal of Geology and Geophysics, 37, 37-47.

Amer, M., Daim, T. U., \& Jetter, A. (2013). A review of scenario planning. Futures, 46, $23-$ 40. https://doi.org/10.1016/j.futures.2012.10.003

Andrews, D. G., Holton, J. R., \& Leovy, C. B. (1987). Middle Atmosphere Dynamics. New York: Academic Press.

Aramaki, S. (1984). Formation of the Aira Caldera, southern Kyushu, 22,000 years ago. Journal of Geophysical Research, 89, 8485-8501. https://doi.org/10.1029/JB089iB10p08485

Aubry, T. J., Jellinek, A. M., Carazzo, G., Gallo, R., Hatcher, K., \& Dunning, J. (2017). A new analytical scaling for turbulent wind-bent plumes: Comparison of scaling laws with analog experiments and a new database of eruptive conditions for predicting the height of volcanic plumes. Journal of Volcanology and Geothermal Research, 343, 233-251. https://doi.org/10.1016/j.jvolgeores.2017.07.006.

Baines, P. G., \& Sparks, R. S. J. (2005). Dynamics of giant volcanic ash clouds from supervolcanic eruptions. Geophysical Research Letters, 32, L24808. https://doi.org/10.1029/2005GL024597

Barker, S. J., Wilson, C. J. N., Allan, A. S. R., \& Schipper, C. I. (2015). Fine-scale temporal recovery, reconstruction and evolution of a post-supereruption magma system. Contributions to Mineralogy and Petrology, 170, 5. https://doi.org/10.1007/s00410-0151155-2

Barker, S. J., Wilson, C. J. N., Morgan, D. J., \& Rowland, J. V. (2016). Rapid priming, accumulation and recharge of magma driving recent eruptions at a hyperactive caldera voleano. Geology, 44, 323-326. https://doi.org/10.1130/G37382.1

Blake, D. M., Deligne, N. I., Wilson, T. M., Lindsay, J. M., \& Woods, R. (2017). Investigating the consequences of urban volcanism using a scenario approach II: Insights 
into transportation network damage and functionality. Journal of Volcanology and Geothermal Research, 340, 92-116 . https://doi.org/10.1016/j.jvolgeores.2017.04.010 Biass, S., Todde, A., Cioni, R., Pistolesi, M., Geshi, N., \& Bonadonna, C. (2017). Potential impacts of tephra fallout from a large-scale explosive eruption at Sakurajima volcano, Japan. Bulletin of Volcanology, 79, 73. https://doi.org/10.1007/s00445-017-1153-5

Bonadonna, C., \& Phillips, J. C. (2003). Sedimentation from strong volcanic plumes. Journal of Geophysical Research, 108, 2340-2368. https://doi.org/10.1029/2002JB002034

Brown, R. J., Bonadonna, C., \& Durant, A. J. (2012). A review of volcanic ash aggregation. Physics and Chemistry of the Earth, Parts A/B/C, 45-46, 65-78. https://doi.org/10.1016/j.pce.2011.11.001

Carey, S., \& Sigurdsson, H. (1989). The intensity of Plinian eruptions. Bulletin of Volcanology, 51, 28-40.

Carey, S., \& Sparks, R. S. J. (1986). Quantitative models of the fallout and dispersal of tephra from yolcanic eruption columns. Bulletin of Volcanology, 48, 109-125.

Carter, L., Alloway, B., Shane, P., \& Westgate, J. (2004). Deep-ocean record of major late Cenozoic rhyolitic eruptions from New Zealand. New Zealand Journal of Geology and Geophysics, 47, 481-500.

Christiansen, R. L. (2001). The Quaternary and Pliocene Yellowstone Plateau Volcanic Field of Wyoming, Idaho, and Montana. U. S. Geological Survey Professional Paper 729-G. Washington, D.C.: United States Government Printing Office.

Christiansen, R. L., Lowenstern, J. B., Smith, R. B., Heasler, H., Morgan, L. A., Nathenson, M., et al. (2007). Preliminary assessment of volcanic and hydrothermal hazards in Yellowstone National Park and vicinity. U. S. Geological Survey Open-File Report 2007-1071. Washington, D.C.: United States Government Printing Office.

Costa, A., Dell' Erba, F. Di Vito, M. A., Isaia, R., Macedonio, G., Orsi, G., \& Pfeiffer, T. (2009). Tephra fallout hazard assessment at the Campi Flegrei caldera (Italy). Bulletin of Volcanology, 71, 259-273. https://doi.org/10.1007/s00445-008-0220-3

Costa, A., Folch, A., \& Macedonio, G. (2013). Density-driven transport in the umbrella region of volcanic clouds: Implications for tephra dispersion models, Geophysical Research Letters, 40, 4823-4827. https://doi.org/10.1002/grl.50942.

Costa, A., Suzuki, Y. J., \& Koyaguchi, T. (2018). Understanding the plume dynamics of explosive super-eruptions. Nature Communications, 9, 654. https://doi.org/10.1038/s41467-018-02901-0 
Coulter, J. D. (1975). The climate. In: G. Kushel (Ed.), Biogeography and Ecology in New Zealand (pp. 87-138). Dr. W. Junk: The Hague, Netherlands.

Craig H., Wilson T., Stewart, C., Villarosa, G., Outes, V., Cronin, S., \& Jenkins, S. (2016). Agricultural impact assessment and management after three widespread tephra falls in Patagonia, South America. Natural Hazards, 82, 1167-1229. http://dx.doi.org/10.1007/s11069-016-2240-1.

Cronin, S. J., Hedley, M. J., Neall, V. E., \& Smith, R. G. (1998). Agronomic impact of tephra fallout from 1995 and 1996 Ruapehu volcanic eruptions, New Zealand. Environmental Geology, 34, 21-30. https://doi.org/10.1007/s002540050253

Davies, T., Beaven, S., Conradson, D., Densmore, A., Gaillard, J. C., Johnston, D., et al. (2015). Towards disaster resilience: A scenario-based approach to co-producing and integräting hazard and risk knowledge. International Journal of Disaster Risk Reduction, 13, 242-247. https://doi.org/10.1016/j.ijdrr.2015.05.009

Degruyter, W., \& Bonadonna, C. (2012). Improving on mass flow rate estimates of volcanic eruptions. Geophysical Research Letters, 39, L16308, https://doi 10.1029/2012GL052566.

Deligne, N. I., Fitzgerald, R. H., Blake, D. M., Davies, A. J., Hayes, J. L., Stewart, C., et al. (2017). Investigating the consequences of urban volcanism using a scenario approach I: Development and application of a hypothetical eruption in the Auckland Volcanic Field, New Zealand. Journal of Volcanology and Geothermal Research, 336, 192-208. https://doi.org/10.1016/j.jvolgeores.2017.02.023

De Lange, P. J., \& Lowe, D.J. (1990). History of vertical displacement of Kerepehi Fault at Kopouatai Bog, Hauraki lowlands, New Zealand, since c. 10700 years ago. New Zealand Journal of Geology and Geophysics, 33, 277-283.

De Natale, G., Troise, C., Kilburn, C. R. J., Somma, R., \& Moretti, R. (2017). Understanding volcanic hazard at the most populated caldera in the world: Campi Flegrei, Southern Italy. Geochemistry, Geophysics, Geosystems, 18, 2004-2008. https://doi.org/10.1002/2017GC006972

Di Vito, M. A., Isaia, R., Orsi, G., Southon, J., de Vita, S., D'Antonio, M. D., et al. (1999). Volcanism and deformation since 12,000 years at the Campi Flegrei caldera (Italy). Journal of Volcanology and Geothermal Research, 91, 221-246. https://doi.org/10.1016/S0377-0273(99)00037-2 
Druitt, T. H., Edwards, L., Mellors, R. M., Pyle, D. M., Sparks, R. S. J., Lanphere, M., et al. (1999). Santorini Volcano. Geological Society Memoirs (Vol. 19). Geological Society, London. https://doi.org/10.1002/esp.205

Dunbar, N. W., Iverson, N. A., Van Eaton, A. R., Sigl, M., Alloway, B. V., Kurbatov, A. V., et al. (2017). New Zealand super-eruption provides time marker for the Last Glacial Maximum in Antarctica. Scientific Reports, 7, 12238. https://doi.org/10.1038/s41598017-11758-0

Durant, A. J., Rose, W. I., Sarna-Wojcicki, A. M., Carey, S., \& Volentik, A. C. (2009). Hydrometeor-enhanced tephra sedimentation: Constraints from the 18 May 1980 eruption of Mount St. Helens (USA). Journal of Geophysical Research, 114, B03204. https://doi.org/10.1029/2008JB005756

Eden, D. N., Froggatt, P. C., Trustrum, N. A., \& Page, M. J. (1993). A multiple-source Holocene tephra sequence from Lake Tutira, Hawke's Bay, New Zealand. New Zealand Journal of Geology and Geophysics, 36, 233-242.

Fero, J., Carey, S. N., \& Merrill J. T. (2009). Simulating the dispersal of tephra from the 1991 Pinatubo eruption: Implications for the formation of widespread ash layers. Journal of Volcanology and Geothermal Research, 186, 120-131. https://doi.org/10.1016/j.jvolgeores.2009.03.011

Folch, A., Costa, A., Durant, A., \& Macedonio, G. (2010). A model for wet aggregation of ash particles in volcanic plumes and clouds: II. Model application. Journal of Geophysical Research, 115, B09202. https://doi.org/10.1029/2009JB007176.

Folch, A. (2012). A review of tephra transport and dispersal models: Evolution, current status, and future perspectives. Journal of Volcanology and Geothermal Research, 235 236, 96-115. https://doi.org/10.1016/j.jvolgeores.2012.05.020.

Froggatt, P. C., \& Rogers, G. M. 1990. Tephrostratigraphy of high-altitude peat bogs along the axial ranges, North Island, New Zealand. New Zealand Journal of Geology and Geophysics, 33, 111-124.

Gehrels, M. J., Lowe, D. J., Hazell, Z. J., \& Newnham, R. M. (2006). A continuous 5300-yr Holocene cryptotephrostratigraphic record from northern New Zealand and implications for tephrochronology and volcanic hazard assessment. Holocene, 16, 173-187. https://doi.org/10.1191/0959683606h1918rp

Hargie, K. A., Van Eaton, A. R., Mastin, L. G., Holzworth, R. H., Ewert, J. W., \& Pavolonis, M. (In Press). Globally detected volcanic lightning and umbrella dynamics during the 
2014 eruption of Kelud, Indonesia. Journal of Volcanology and Geothermal Research, https://doi.org/10.1016/j.jvolgeores.2018.10.016

Hildreth, W. (2004). Volcanological perspectives on Long Valley, Mammoth Mountain, and Mono Craters: several contiguous but discrete systems. Journal of Volcanology and Geothermal Research, 136, 169-198. https://doi.org/10.1016/j.jvolgeores.2004.05.019

Hogg, A. G., Lowe, D. J., Palmer, J., Boswijk, G., \& Ramsey C. B. (2012). Revised calendar date for the Taupo eruption derived by ${ }^{14} \mathrm{C}$ wiggle-matching using a New Zealand kauri ${ }^{14} \mathrm{C}$ calibration data set. Holocene, 22, 439-449. https://doi.org/10.1177/0959683611425551

Holasek, R. E., Self, S., \& Woods, A. W. (1996). Satellite observations and interpretation of the 1991 Mount Pinatubo eruption plumes. Journal of Geophysical Research, 101, 27635-27656. https://doi.org/10.1029/96JB01179

Houghton, B. F., Carey, R. J., Cashman, K. V., Wilson, C. J. N., Hobden, B. J., \& Hammer, J. E. (2010). Diverse patterns of ascent, degassing, and eruption of rhyolite magma during the $1.8 \mathrm{ka}$ Taupo eruption, New Zealand: evidence from clast vesicularity. Journal of Volcanology and Geothermal Research, 195, 31-47. https://doi.org/10.1016/j.jvolgeores.2010.06.002

Houghton, B. F., Carey, R. J., Rosenberg, M. D. (2014). The 1800a Taupo eruption: "Ill wind" blows the ultraplinian type event down to Plinian. Geology, 42, 459-461. https://doi.org/10.1130/G35400.1

Howorth, R., Froggatt, P. C., \& Robertson, S. M. (1980). Late Quaternary volcanic ash stratigraphy of the Poukawa area, central Hawke's Bay. New Zealand Journal of Geology and Geophysics, 23, 487-491.

Hubbard, C. B., \& Neall, V. E. (1980). A reconstruction of late Quaternary events in the West Tamaki catchment, southern Ruahine Range, North Island. New Zealand Journal of Geology and Geophysics, 23, 587-593.

Hurst, T., \& Davis, C. (2017). Forecasting volcanic ash deposition using HYSPLIT. Journal of Applied Volcanology, 6, 5. https://doi.org/10.1186/s13617-017-0056-7

Hurst, T., \& Smith, W. (2004). A Monte Carlo methodology for modelling ashfall hazards. Journal of Volcanology and Geothermal Research, 138, 393-403.

https://doi.org/10.1016/j.jvolgeores.2004.08.001

Hurst, T., \& Smith, W. (2010). Volcanic ashfall in New Zealand - probabilistic hazard modelling from multiple sources. New Zealand Journal of Geology and Geophysics, 53, 1-14. https://doi.org/10.1080/00288301003631129 
Jenkins, S. F., Wilson, T. M., Magill, C. R., Miller, V., Stewart, C., Blong, R., et al. (2015). Volcanic ash fall hazard and risk. In S.C. Loughlin, R. S. J. Sparks, S. K. Brown, S. F. Jenkins and C. Vye-Brown (Eds.), Global Volcanic Hazards and Risk (pp. 173-222). Cambridge: Cambridge University Press. https://doi.org/10.1017/CBO9781316276273 Jiang, N., Hay, J. E., \& Fisher G. W. (2006). Classification of New Zealand synoptic weather types and relation to the Southern Oscillation Index. Weather and Climate, 25, 43-70.

Jiang, N., Griffiths, G., \& Lorrey, A. (2012). Influence of large-scale climate modes on daily synoptic weather types over New Zealand. International Journal of Climatology, 33, 499-519. https://doi.org/10.1002/joc.3443

Johnston, D. M., Houghton, B. F., Neall, V. E., Ronan, K. R., \& Paton, D. (2000). Impacts of the 1945 and 1995-1996 Ruapehu eruptions, New Zealand: An example of increasing societal vulnerability. Geological Society of America Bulletin, 112, 720-726.

Kalnay, E., Kanamitsu, M., Kistler, R., Collins, W., Deaven, D., Gandin, L., et al. (1996). The NCEP/NCAR 40-year reanalysis project. Bulletin of the American Meteorological Society, 77, 437-471.

Kidson, J. W. (2000). An analysis of New Zealand synoptic types and their use in defining weather regimes, International Journal of Climatology, 20, 299-316.

Koyaguchi, T., \& Woods, A. W. (1996). On the formation of eruption columns following explosive mixing of magma and surface-water. Journal of Geophysical Research, 101, $5561-5574$

Langmann, B., Folch, A., Hensch, M., \& Matthias, V. (2012). Volcanic ash over Europe during the eruption of Eyjafjallajökull on Iceland, April-May 2010. Atmospheric Environment, 48, 1-8. https://doi.org/10.1016/j.atmosenv.2011.03.054

Lorrey, A. M., Vandergoes, M., Almond, P., Renwick, J. Stephens, T., Bostock, H., et al. (2012). Palaeocirculation across New Zealand during the last glacial maximum at $\sim 21$ ka. Quaternary Science Reviews, 36, 189-213. https://doi.org/10.1016/j.quascirev.2011.09.025

Lowe, D. J. (1988a). Late Quaternary volcanism in New Zealand: towards an integrated record using distal airfall tephras in lakes and bogs. Journal of Quaternary Science, 3, $111-120$.

Lowe, D. J. (1988b). Stratigraphy, age, composition, and correlation of late Quaternary tephras interbedded with organic sediments in Waikato lakes, North Island, New Zealand. New Zealand Journal of Geology and Geophysics, 31, 125-165. 
Lowe, D. J., Newnham, R. M., \& Ward, C. M. (1999). Stratigraphy and chronology of a 15 ka sequence of multi-sourced silicic tephras in a montane peat bog, eastern North Island, NewZealand. New Zealand Journal of Geology and Geophysics, 42, 565-579. https://doi.org/10.1080/00288306.1999.9514863.

Lowe, D. J., Shane, P. A. R., Alloway, B. V., \& Newnham, R. M. (2008). Fingerprints and age models for widespread New Zealand tephra marker beds erupted since 30,000 years ago: a framework for NZ-INTIMATE. Quaternary Science Reviews, 27, 95-126. https://doi.org/10.1016/j.quascirev.2007.01.013

Lowe, D. J., Blaauw, M., Hogg, A. G., \& Newnham, R. M. (2013). Ages of 24 widespread tephras erupted since 30000 years ago in New Zealand, with re-evaluation of the timing and palaeoclimatic implications of the Lateglacial cool episode recorded at Kaipo bog. Quaternary Science Reviews, 74, 170-194. http://dx.doi.org/10.1016/j.quascirev.2012.11.022

Lowenstern, J. B., Smith, R. B., \& Hill, D. P. (2006). Monitoring super-volcanoes: Geophysical and geochemical signals at Yellowstone and other large caldera systems. Philosophical Transactions of the Royal Society of London, Series A, 364, 2055-2072. https://doi.org/10.1098/rsta.2006.1813

Macedonio, G., \& Costa, A. (2012). Rain effect on the load of tephra deposits, Natural Hazards and Earth Systems Science, 12, 1229-1233. https://doi.org/10.5194/nhess-121229-2012

Maeno, F., Nakada, S., Yoshimoto, M., Shimano, T., Hokanishi, N., Zaennudin, A., \& Iguchi, M. (In Press). A sequence of a plinian eruption preceded by dome destruction at Kelud volcano, Indonesia, on February 13, 2014, revealed from tephra fallout and pyroclastic density current deposits. Journal of Volcanology and Geothermal Research. https://doi.org/10.1016/j.jvolgeores.2017.03.002

Marti, A., Folch, A., Costa, A. \& Engwell, A. (2016). Reconstructing the plinian and coignimbrite sources of large volcanic eruptions: a novel approach for the Campanian Ignimbrite. Scientific Reports, 6, 21220. https://doi.org/10.1038/srep21220

Mastin, L. G., Guffanti, M., Servranckx, R., Webley, P., Barsotti, S., et al. (2009). A multidisciplinary effort to assign realistic source parameters to models of volcanic ashcloud transport and dispersion during eruptions. Journal of Volcanology and Geothermal Research, 186, 10-21. https://doi.org/10.1016/j.jvolgeores.2009.01.008 
Mastin, L. G., Van Eaton, A. R., \& Lowenstern, J. B. (2014). Modeling ash fall distribution from a Yellowstone supereruption. Geochemistry, Geophysics, Geosystems, 15, 34593475. https://doi.org/10.1002/2014GC005469

Mastin, L. G., Van Eaton, A. R., \& Durant, A. J. (2016). Adjusting particle-size distributions to account for aggregation in tephra-deposit model forecasts. Atmospheric Chemistry and Physics, 16, 9399-9420. https://doi.org/10.5194/acp-16-9399-2016

Newnham, R. M., Lowe, D. J., Green, J .D., Turner, G. M., Harper, M. A., McGlone, M. S., et al. (2004). A discontinuous ca. 80 ka record of Late Quaternary environmental change from Lake Omapere, Northland, New Zealand. Palaeogeography, Palaeoclimatology, Palaeoecology, 207, 165-198. https://doi.org/10.1016/j.palaeo.2004.02.007

Oppenheimer, C. (2003). Climatic, environmental and human consequences of the largest known historic eruption: Tambora volcano (Indonesia) 1815. Progress in Physical Geography, 27, 230-259.

Parks, M. M., Biggs, J., England, P., Mather, T. A., Nomikou, P., Palamartchouk, K., et al. (2012). Evolution of Santorini Volcano dominated by episodic and rapid fluxes of melt from depth. Nature Geoscience, 5, 749-754. https://doi.org/10.1038/ngeo1562

Potter, S. H., Scott, B. J., Jolly, G. E., Johnston, D. M., \& Neall, V. E. (2015). A catalogue of caldera unrest at Taupo Volcanic Centre, New Zealand, using the Volcanic Unrest Index (VUI). Bulletin of Volcanology, 77, 9. https://doi.org/10.1007/s00445-015-0956-5

Pullar, W. A., Kohn, B. P., \& Cox, J. E. (1977). Air-fall Kaharoa Ash and Taupo Pumice, and sea-rafted Loisels Pumice, Taupo Pumice, and Leigh Pumice in northern and eastern parts of the North Island, New Zealand. New Zealand Journal of Geology and Geophysics, 20, 697-717.

Renwick, J. A. (2011). Kidson's synoptic weather types and surface climate variability over New Zealand. Weather and Climate, 31, 3-32.

Rhoades, D. A., Dowrick, D. J., \& Wilson, C. J. N. (2002). Volcanic hazards in New Zealand: Scaling and attenuation relations for tephra fall deposits from Taupo volcano. Natural Hazards, 26, 147-174. https://doi.org/10.1023/A:1015608732356

Roebber, P., Schultz, D., Colle, B., \& Stensrud, D. (2004). Toward improved prediction: High-resolution and ensemble modeling systems in operations. Weather and Forecasting, 19, 936-949.

Rose, W. I., \& Durant, A. J. (2009). Fine ash content of explosive eruptions. Journal of Volcanology and Geothermal Research, 186, 32-39. https://doi.org/10.1016/j.jvolgeores.2009.01.010 
Rowland, J. V., Wilson, C. J. N., \& Gravley, D. M. (2010). Spatial and temporal variations in magma-assisted rifting, Taupo Volcanic Zone, New Zealand. Journal of Volcanology and Geothermal Research, 190, 89-108. https://doi.org/10.1016/j.jvolgeores.2009.05.004

Sandri, L., Costa, A., Selva, J., Tonini, R., Macedonio, G., Folch, A., \& Sulpizio, R. (2016). Beyond eruptive scenarios: Assessing tephra fallout hazard from Neapolitan volcanoes. Scientific Reports, 6, 24271. https://doi.org/10.1038/srep24271

Schwaiger, H., Denlinger, R., \& Mastin, L. G. (2012). Ash3d: A finite-volume, conservative numerical model for ash transport and tephra deposition. Journal of Geophysical Research, 117, B04204. https://doi.org/10.1029/2011JB008968

Self, S. (2006). The effects and consequences of very large explosive volcanic eruptions. Philosophical Transactions of the Royal Society of London, Series A, 364, 2073-2097. https://doi.org/10.1098/rsta.2006.1814

Self, S., Rampino, M. R., Newton, M. S., \& Wolff, J. A. (1984). Volcanological study of the great Tambora eruption of 1815. Geology, 12, 659-663.

Sigurdsson, H., \& Carey, S. (1989). Plinian and co-ignimbrite tephra fall from the 1815 eruption of Tambora volcano. Bulletin of Volcanology, 51, 243-270.

Smith, E. G. C., Williams, T. D., \& Darby, D. J. (2007). Principal component analysis and modeling of the subsidence of the shoreline of Lake Taupo, New Zealand, 1983-1999: Evidence for dewatering of a magmatic intrusion? Journal of Geophysical Research, 112, B08406. https://doi.org/10.1029/2006JB004652

Sparks, R. S. J., Bursik, M. I., Carey, S. N., Gilbert, J. S., Glaze, L., Sigurdsson, H., Woods, A. W. (1997). Volcanic Plumes. Chichester, U.K: Wiley.

Stewart, C., Craig, H. M., Gaw, S., Wilson, T., Villarosa, G., Outes V., et al. (2016). Fate and agricultural consequences of leachable elements added to the environment from the 2011 Cordón Caulle tephra fall. Journal of Volcanology and Geothermal Research, 327, 554 570. http://dx.doi.org/10.1016/j.jvolgeores.2016.09.017.

Stirling, M. W., \& Wilson, C. J. N. (2002). Development of a volcanic hazard model for New Zealand: First approaches from the methods of seismic hazard analysis. Bulletin of the New Zealand Society for Earthquake Engineering, 35, 266-277.

Sturman, A. P., \& Tapper, N. J. (2008). The Weather and Climate of Australia and New Zealand. New York: Oxford University Press. 
Suzuki, T. (1983). A theoretical model for dispersion of tephra. In D. Shimozuru and I. Yokoyama (Eds.), Arc Volcanism: Physics and Tectonics (pp. 95-113). Tokyo: Terra Scientific Publishing Company.

Suzuki, Y.J., \& Koyaguchi, T. (2009). A three-dimensional numerical simulation of spreading umbrella clouds. Journal of Geophysical Research, 114, B03209. https://doi.org/10.1029/2007JB005369.

Suzuki, Y. J., Costa, A., Cerminara, M., Esposti Ongaro, T., Herzog, M., Van Eaton, A. R., \& Denby, L. C. (2016). Inter-comparison of three-dimensional models of volcanic plumes. Journal of Volcanology and Geothermal Research, 326, 26-42. https://doi.org/10.1016/j.jvolgeores.2016.06.011

Thompson, M. A., Lindsay, J. M., Sandri, L., Biass, S., Bonadonna, C., Jolly, G., \& Marzocchi, W. (2015). Exploring the influence of vent location and eruption style on tephra fall hazard from the Okataina Volcanic Centre, New Zealand. Bulletin of Volcanology, 77, 38. https://doi.org/10.1007/s00445-015-0926-y

Van Eaton, A. R., \& Wilson, C. J. N. (2013). The nature, origins and distribution of ash aggregates in a large-scale wet eruption deposit: Oruanui, New Zealand. Journal of Volcanology and Geothermal Research, 250, 129-154. https://doi.org/10.1016/j.jvolgeores.2012.10.016

Van Eaton, A. R., Herzog, M., Wilson, C. J. N., \& McGregor, J. (2012a). Ascent dynamics of large phreatomagmatic eruption clouds: the role of microphysics. Journal of Geophysical Research, 117, B03203. https://doi.org/10.1029/2011JB008892

Van Eaton, A. R., Muirhead, J. D., Wilson C. J. N., \& Cimarelli, C. (2012b). Growth of volcanic ash aggregates in the presence of liquid water and ice: An experimental approach. Bulletin of Volcanology, 74, 1963-1984. https://doi.org/10.1007/s00445-0120634-9

Van Eaton, A. R., Mastin, L. G., Herzog, M., Schwaiger H. F., Schneider D. J., Wallace K. L, \& Clarke A. B. (2015). Hail formation triggers rapid ash aggregation in volcanic plumes. Nature Communications, 6, 7860. https://doi.org/10.1038/ncomms8860.

Van Eaton, A. R., Amigo, À., Bertin, D., Mastin, L. G., Giacosa, R. E., González, J., et al. (2016). Volcanic lightning and plume dynamics reveal evolving hazards during the April 2015 eruption of Calbuco volcano, Chile. Geophysical Research Letters, 43, 3563-3571. https://doi.org/10.1002/2016GL068076

Vandergoes, M. J., Hogg, A. G., Lowe, D. J., Newnham, R. M., Denton, G. H., Southon, J., et al. (2013). A revised age for the Kawakawa/Oruanui Tephra, a key marker for the Last 
Glacial Maximum in New Zealand. Quaternary Science Reviews, 74, 195-201. https://doi.org/10.1016/j.quascirev.2012.11.006

Walker, G. P. L. (1981a). Characteristics of two phreatoplinian ashes and their water-flushed origin. Journal of Volcanology and Geothermal Research, 9, 395-407. https://doi.org/10.1016/0377-0273(81)90046-9

Walker, G. P. L. (1981b). The Waimihia and Hatepe plinian deposits from the rhyolitic Taupo Volcanic Centre. New Zealand Journal of Geology and Geophysics, 24, 305-324.

Wilson, C. J. N. (1993). Stratigraphy, chronology, styles and dynamics of late Quaternary eruptions from Taupo volcano, New Zealand. Philosophical Transactions of the Royal Society of London, Series A, 343, 205-306. https://doi.org/10.1098/rsta.1993.0050

Wilson, C. J. N. (2001). The 26.5 ka Oruanui eruption, New Zealand: an introduction and overview. Journal of Volcanology and Geothermal Research, 112, 133-174. https://doi.org/10.1016/S0377-0273(01)00239-6

Wilson, C. J. N. (2017). Volcanoes: characteristics, tipping points and those pesky unknown unknowns. Elements, 13, 41-46. https://doi.org/10.2113/gselements.13.1.41

Wilson, C. J. N., \& Hildreth, W. (1997). The Bishop Tuff: New insights from eruptive stratigraphy. Journal of Geology, 105, 407-439. https://doi.org/10.1086/515937

Wilson, C. J. N., \& Walker, G. P. L. (1985). The Taupo eruption, New Zealand. I. General aspects. Philosophical Transactions of the Royal Society of London, Series A, 314, 199228. https://doi.org/10.1098/rsta.1985.0019

Wilson, C. J. N., Gravley, D. M., Leonard, G. S., \& Rowland, J. V. (2009). Volcanism in the central Taupo Volcanic Zone, New Zealand: Tempo, styles and controls. In: T. Thordarson, S. Self, G. Larsen, S. K. Rowland and A. Hoskuldsson (Eds.), Studies in Volcanology: The Legacy of George Walker. London: Geological Society. Special Publications of IAVCEI, 2, 225-247.

Wilson, L., \& Huang, T. C. (1979). The influence of shape on the atmospheric settling velocity of volcanic ash particles. Earth and Planetary Science Letters, 44, 311-324.

Wilson, T., Cole, J., Cronin, S., Stewart, C. \& Johnston, D. (2011). Impacts on agriculture following the 1991 eruption of Vulcan Hudson, Patagonia: lessons for recovery. Natural Hazards, 57, 185-212. http://dx.doi.org/10.1007/s11069-010-9604-8.

Wilson, T. M., Stewart, C., Sword-Daniels, V., Leonard, G. S., Johnston, D. M., Cole, J. W., et al. (2012). Volcanic ash impacts on critical infrastructure. Physics and Chemistry of the Earth, 45-46, 5-23. https://doi.org/10.1016/j.pce.2011.06.006 
Woods, A. W., \& Kienle, J. (1994). The dynamics and thermodynamics of volcanic clouds: Theory and observations from the April 15 and April 21, 1990 eruptions of Redoubt Volcano, Alaska. Journal of Volcanology and Geothermal Research, 62, 273-299. Yarnal, B. (1993). Synoptic Climatology in Environmental Analysis. London: Bellhaven Press.

Zawalna-Geer, A., Lindsay, J. M., Davies, S., Augustinus, P., \& Davies, S. (2016). Extracting a primary Holocene cryptotephra record from Pupuke maar sediments, Auckland, New Zealand. Journal of Quaternary Science, 31, 442-457. https://doi.org/10.1002/jqs.2866.
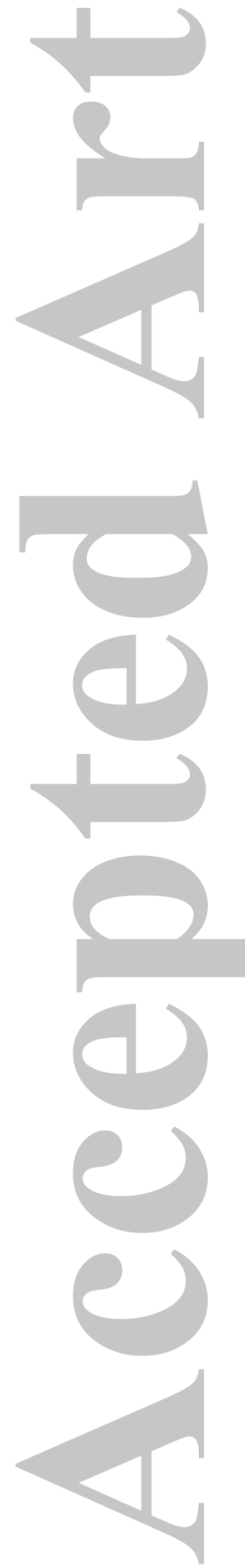

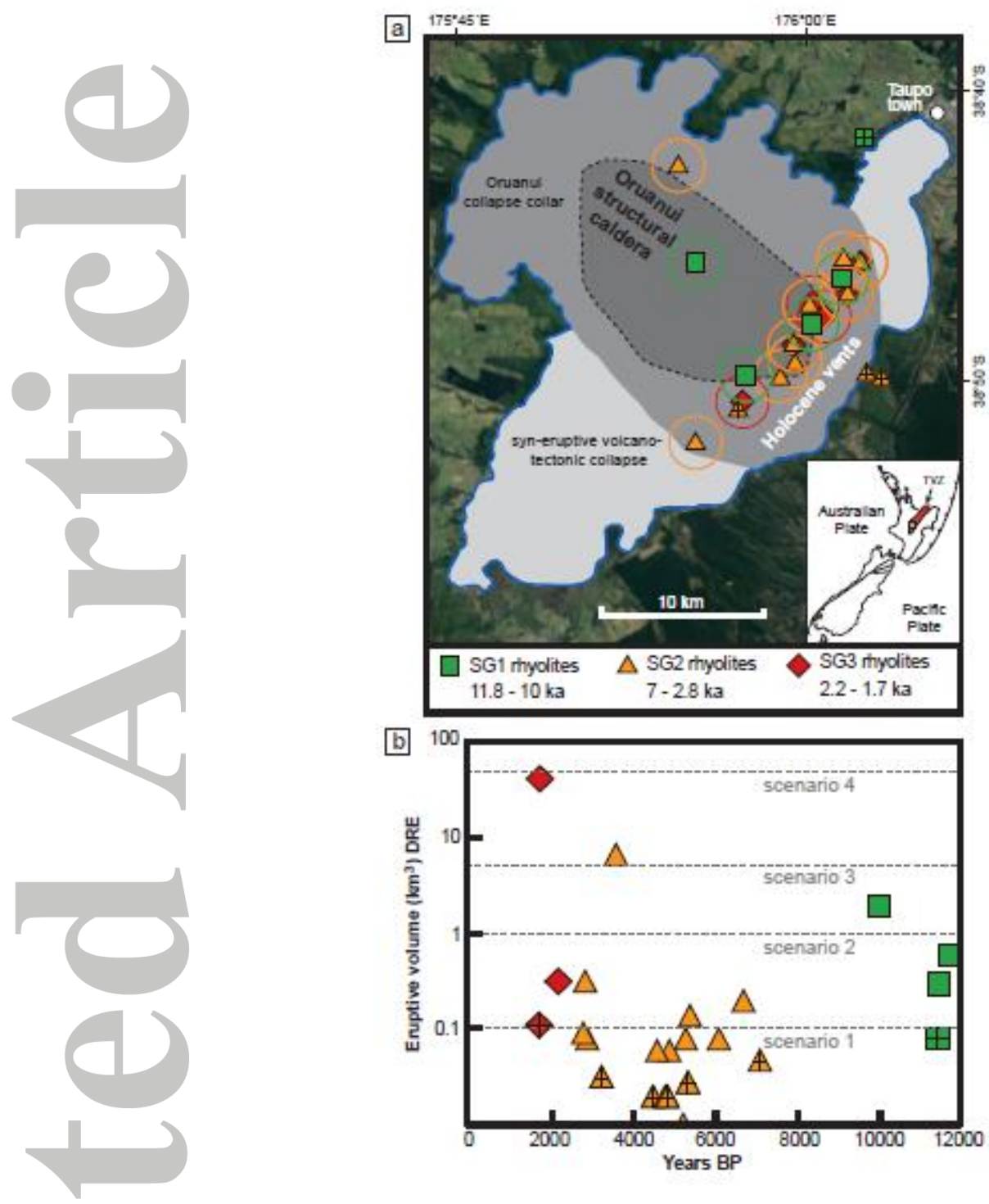

Figure 1. (a) Structural and volcanic features of Taupo volcano, New Zealand (map inset). Blue line is the outline of Lake Taupo. Vent sites with error ellipses and ages for postOruanui eruptions are after Wilson (1993) and Oruanui structural caldera is from Wilson (2001). TVZ_-Taupo Volcanic Zone; SG—subgroup after Barker et al. (2015). (b) Erupted magma volumes in Dense Rock Equivalent (DRE) from Taupo over the Holocene. Grey dashed lines represent boundaries between scenarios identified in this study. Symbols marked with a cross represent vent sites for dominantly effusive eruptions (see text for details).

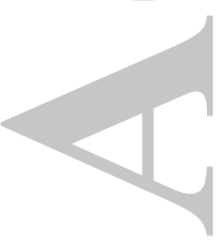




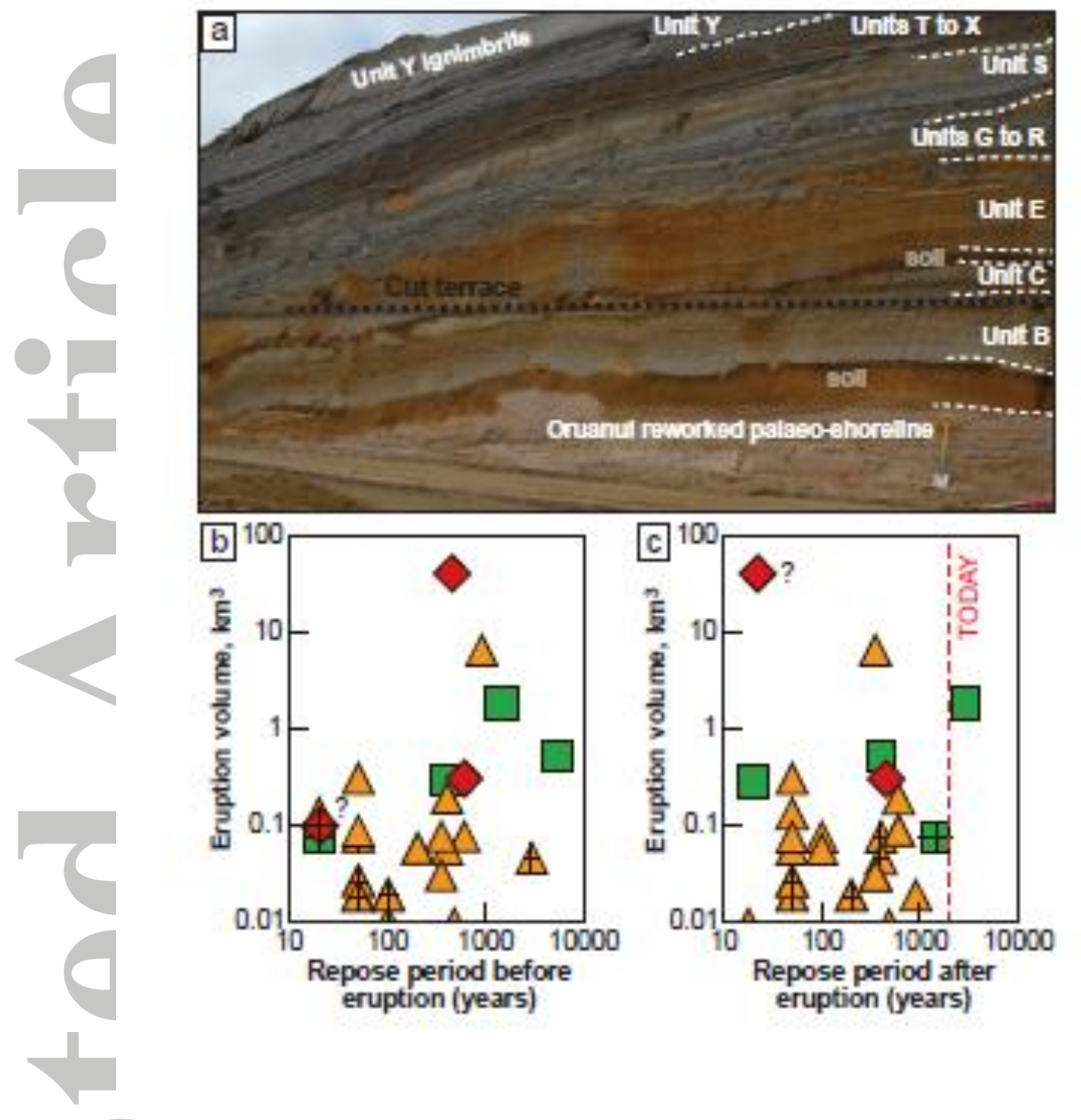

Figure 2. (a) Photo of a road cutting outcrop showing the Holocene eruptive record from Taupo. White labels and dashed lines show the major eruptive units and bracketing palaeosols (soils) for reference. (b) Relationships between the volume of an eruption and the length of the repose period preceding an eruption or (c) following that eruption. Red dashed line shows today for reference, after Wilson et al. (2009). Age and volume data are from Wilson (1993). Symbols as in Figure 1. 

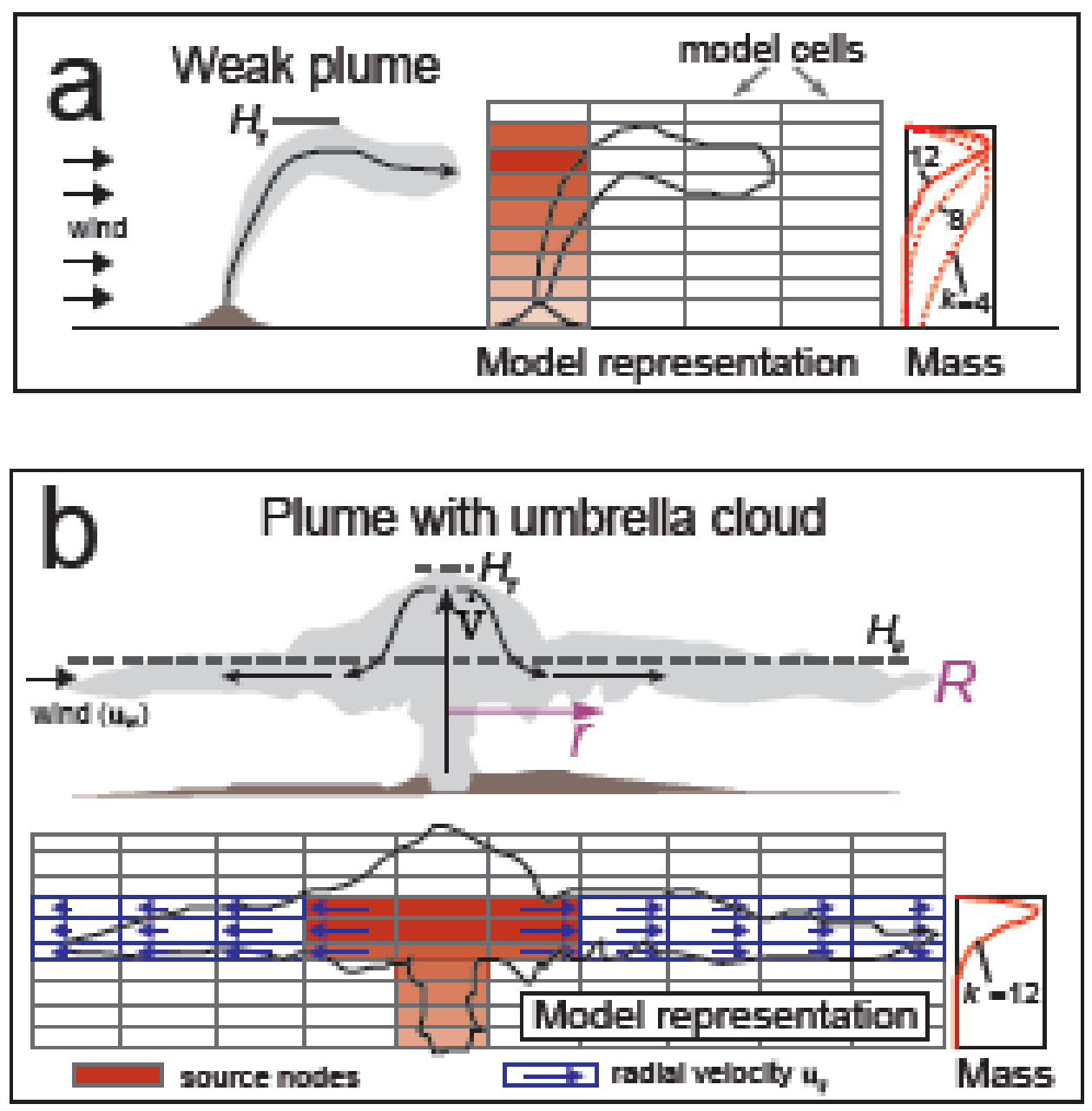

Figure 3. (a) Typical weak plume (left), and a depiction (middle) of the configuration of source nodes (red cells) used in the version of Ash3d in the absence of an umbrella cloud. On the right is an illustration of the distribution of mass with height in the plume, using different values of the Suzuki (1983) factor $k . \mathrm{H}_{\mathrm{T}}$ is the height to the top of the plume (b) Shape of a plume with a large umbrella cloud (top), and a depiction (bottom left) of the configuration of source nodes (red) used to model the umbrella cloud in the modified version of Ash $3 \mathrm{~d} . \mathrm{H}_{\mathrm{u}}$ is the height of the top of the umbrella region, $\dot{V}$ is the volume rate of injection of air, gas, particles into the plume, $r$ is the distance from the cloud center and $R$ is the umbrella cloud radius. A radial velocity field ( $u_{r}$ : blue arrows) is added to the ambient atmospheric wind field $\left(u_{w}\right)$ within the umbrella cloud, as described in the text. For simulations using the umbrella cloud modifications, we use a Suzuki $k$ value of 12 , which distributes mass as illustrated in the lower right. 

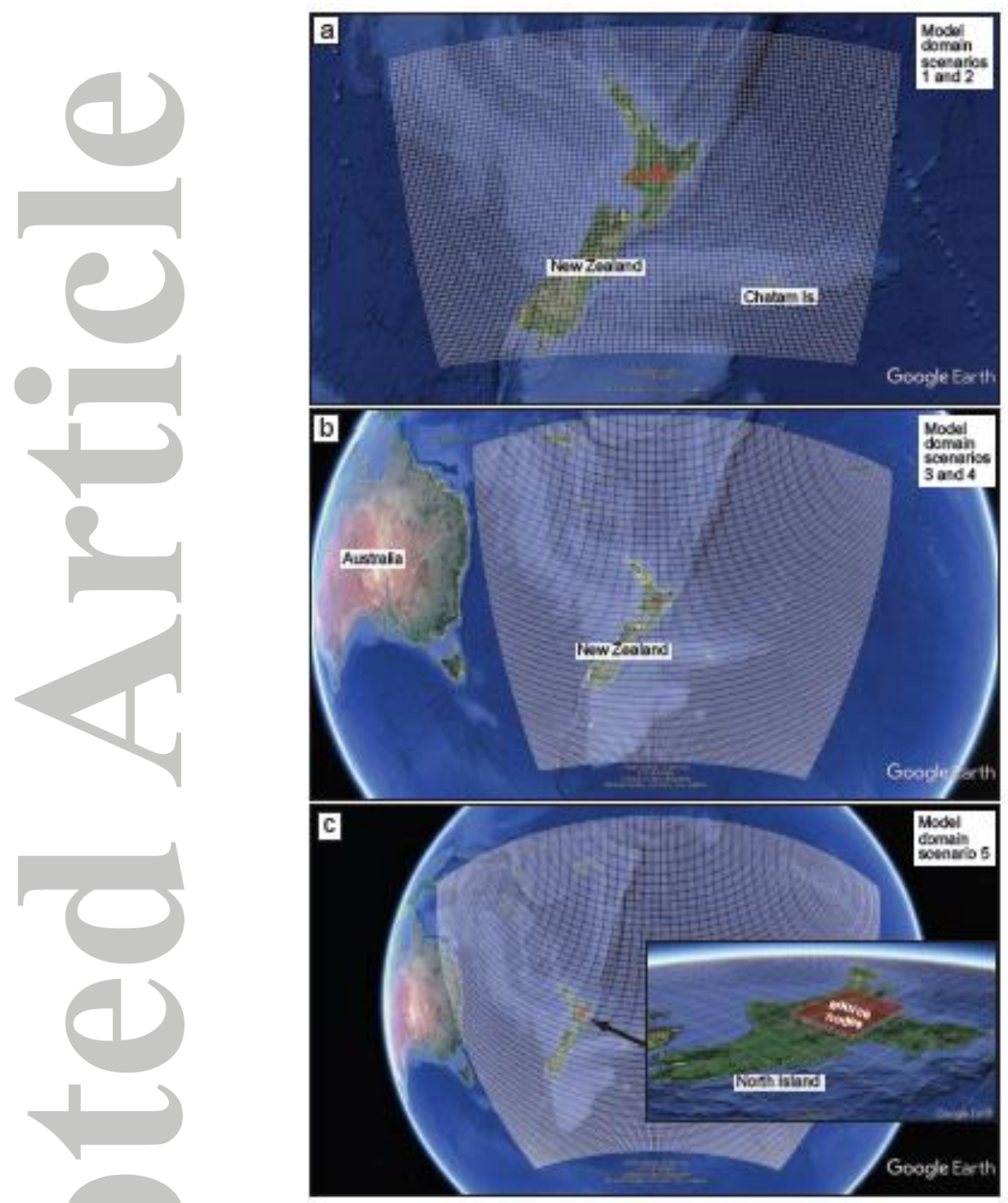

Figure 4. Illustration in Google Earth ${ }^{\circledR}$ of the model domains used for the Taupo model simulations for (a) scenarios 1 and 2 using a $0.25^{\circ}$ nodal spacing, (b) scenarios 3 and 4 using a $0.35^{\circ}$ nodal spacing, and (c) Scenario 5 with a $0.35^{\circ}$ nodal spacing and image inset to show the source nodes of the umbrella cloud from which ash is dispersed. Copyrighted images by Google (2011), Europa Technologies (2011), Tele Atlas, and Geocenter Consulting. Use of these images is consistent with usage allowed by Google

(http://www.google.com/permissions/geoguidelines.html) and do not require explicit permission for publication. 

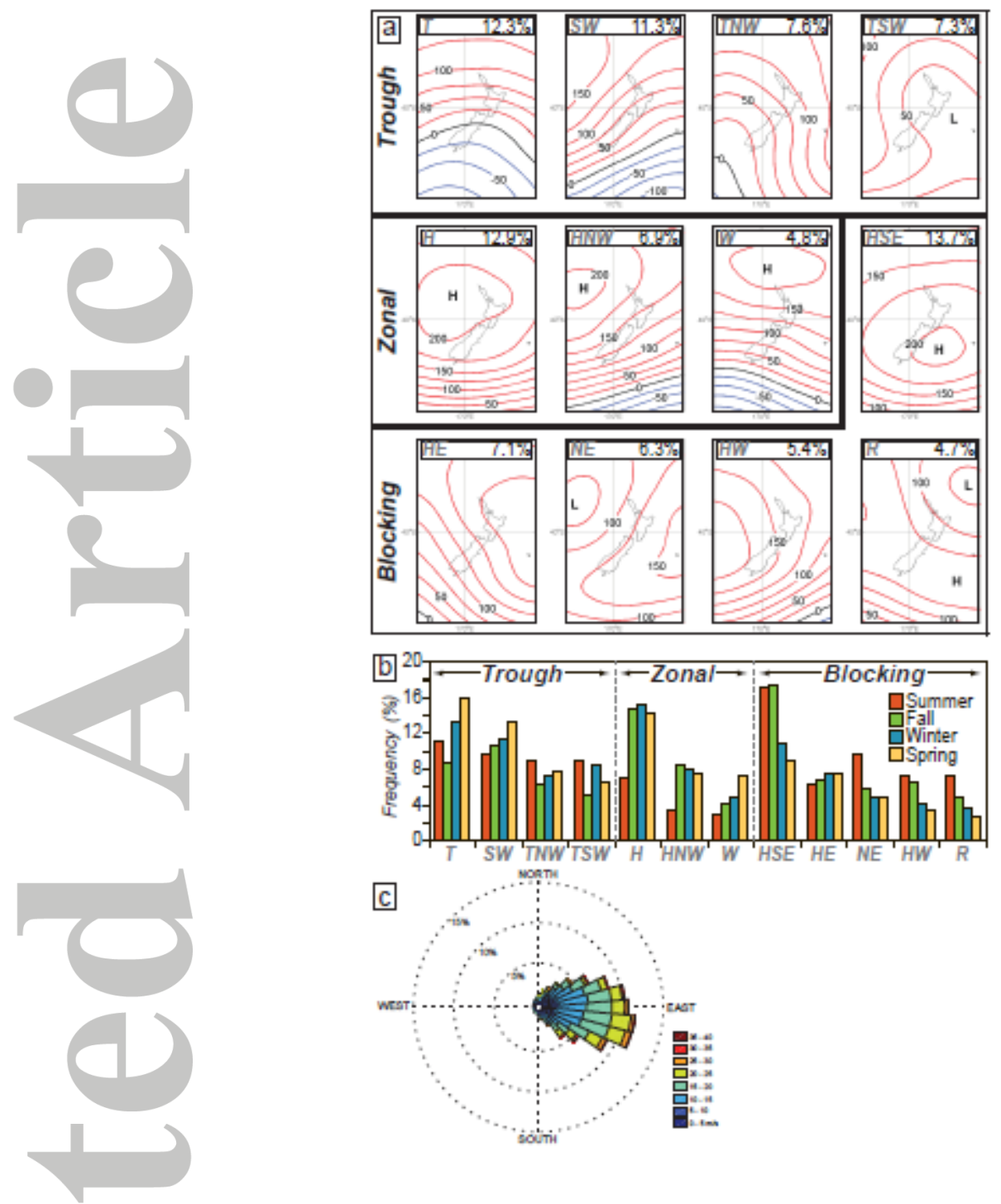

Figure 5. (a) The twelve Kidson weather classifications, shown as average patterns of the height (in meters) of the $1000 \mathrm{hPa}$ pressure surface (analogous to sea-level pressure). The contour interval is $25 \mathrm{~m}$. Names for the synoptic types are indicated in the top left of each panel and the $\%$ average annual occurrences are shown at the top right (see text for details). The three main regimes are indicated at the left. See Kidson (2000) and Renwick (2011) for further details. (b) Histograms showing the seasonal variability of Kidson types and their associated regimes from Kidson (2000). (c) Wind rose diagrams showing wind travel direction (i.e., westerly winds blow from east to west) and speed at Taupo at elevations of $<5$ $\mathrm{km}$. Sampling period is for every 12 hours from 1990-2010 from the NCEP Reanalysis-1 database (Kalnay et al., 1996). See supporting information Figures S4 to S8 for additional diagrams at greater heights and by season. 


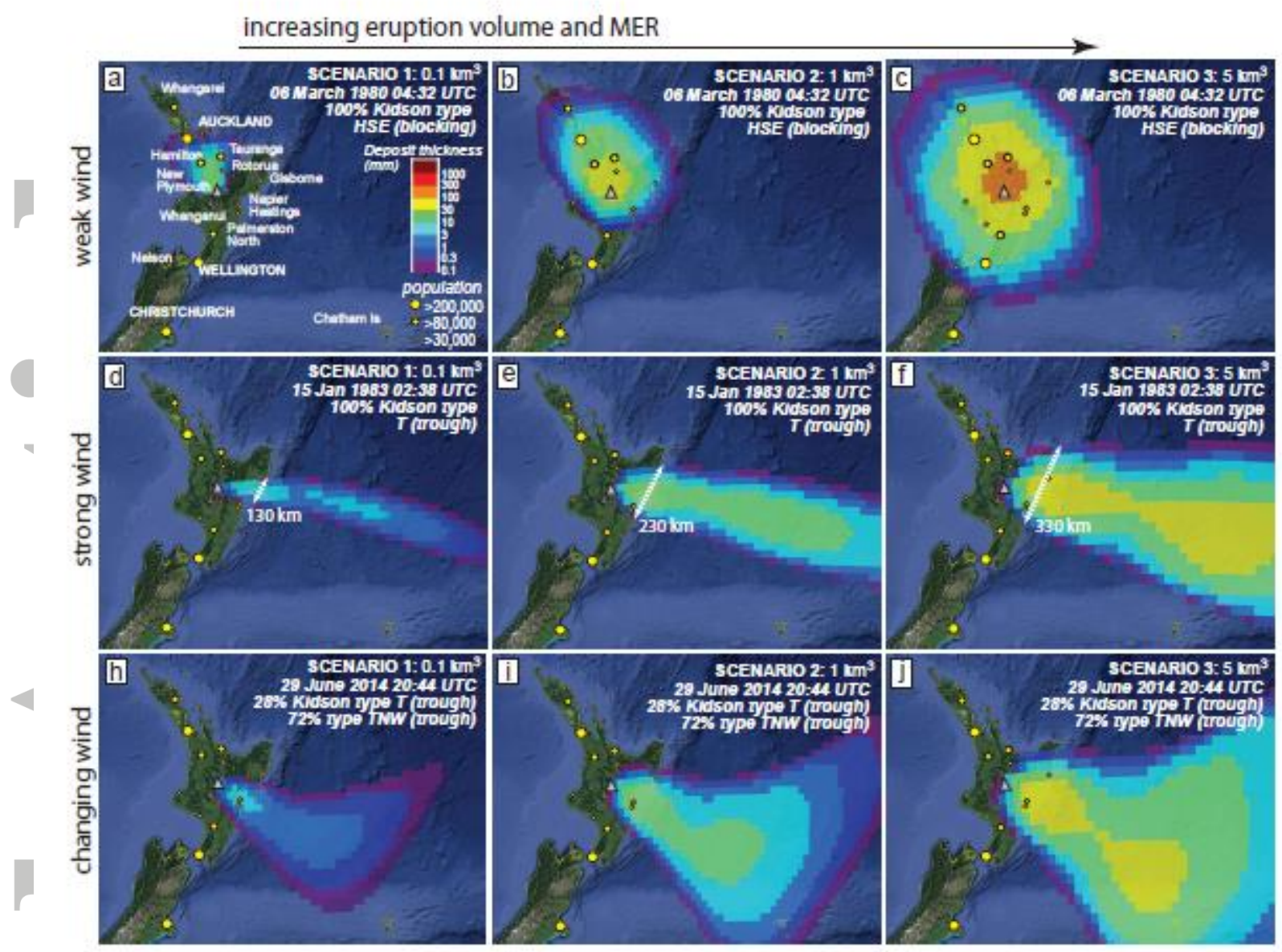

Figure 6. Selected examples of model outputs from individual Ash3d simulations showing final ash deposit thickness (0.1 mm minimum) across New Zealand for small to medium sized eruptions. Diagrams from left to right show increasing eruption sizes from scenarios 1-3 $\left(0.1 \mathrm{~km}^{3}\right.$ to $5 \mathrm{~km}^{3}$ erupted volume) but with the same eruption start times and weather conditions such that (a) to (c) show constant light wind conditions, (d) to (f) show constant strong westerly wind conditions and $(\mathrm{h})$ to $(\mathrm{j})$ show changing wind conditions. Note the secondary thickness maxima in (f) and (j) arising from the used of an aggregated grainsize distribution (Mastin et al., 2016). The percentage of synoptic Kidson weather regime from Figure 5 and start date and time of the eruption are shown at the top right of each panel.

Major population centers are labeled in (a) for reference. See text for further details and Table 1 for details on the eruption scenarios. Base maps are from (C) 2018 Google Earth, as in Figure 4. Vent location indicated by grey triangle. 


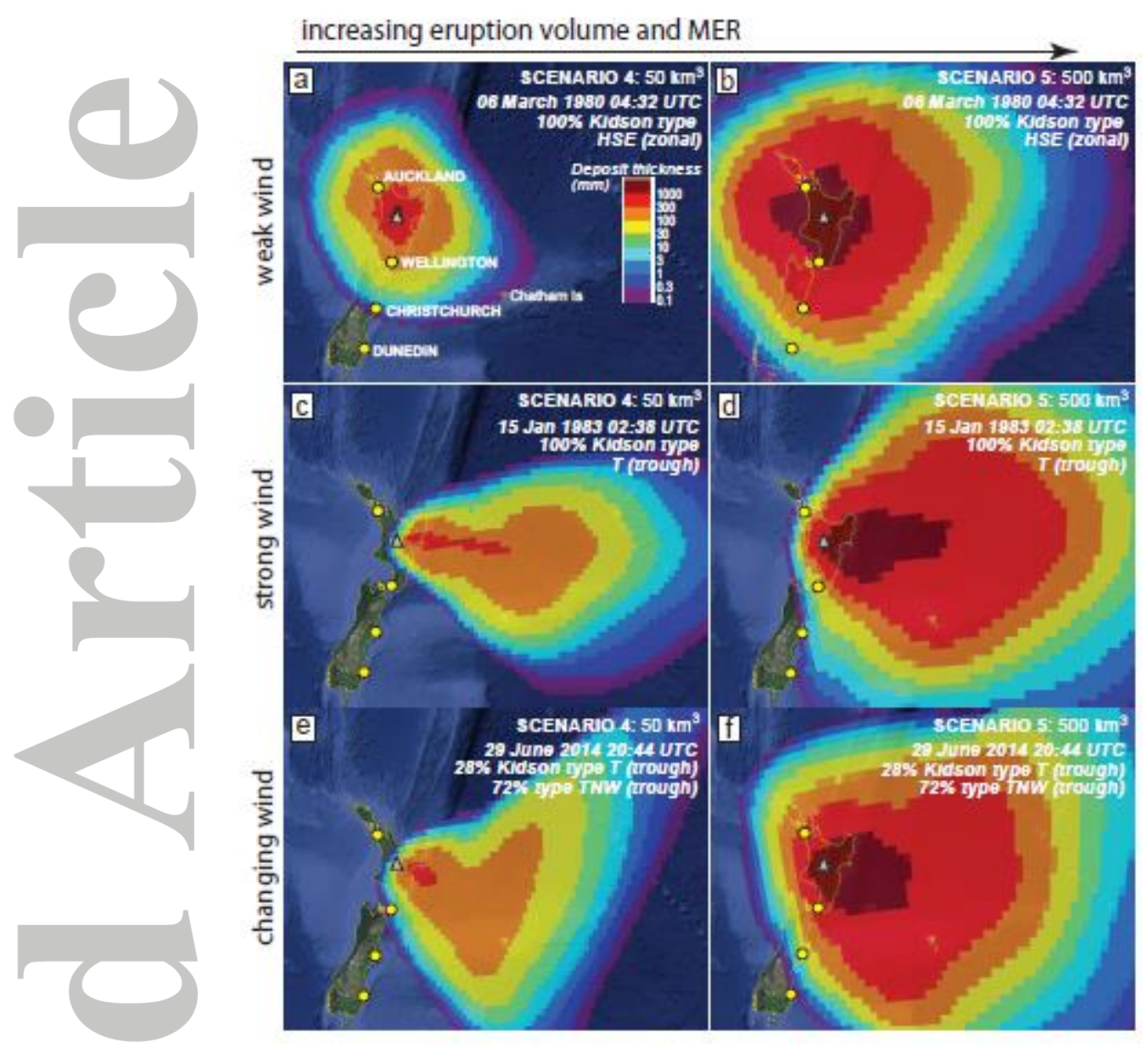

Figure 7. Selected examples of model outputs from individual Ash3d simulations showing final ash deposit thicknesses across New Zealand. Diagrams from left to right show increasing eruption sizes from scenarios $4-5\left(50 \mathrm{~km}^{3}\right.$ to $500 \mathrm{~km}^{3}$ erupted volume) but with the same eruption start times and weather conditions such that (a) and (b) show constant light wind conditions, (c) and (d) show constant strong westerly wind conditions and (e) and (f) show changing wind conditions. Other details as in Figure 6, but note the change in geographical scale.

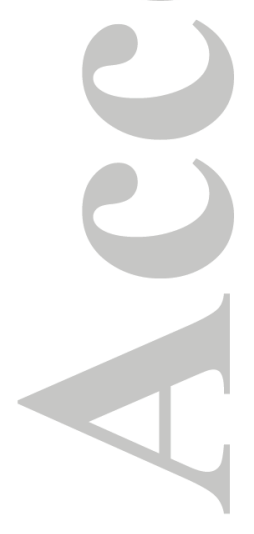




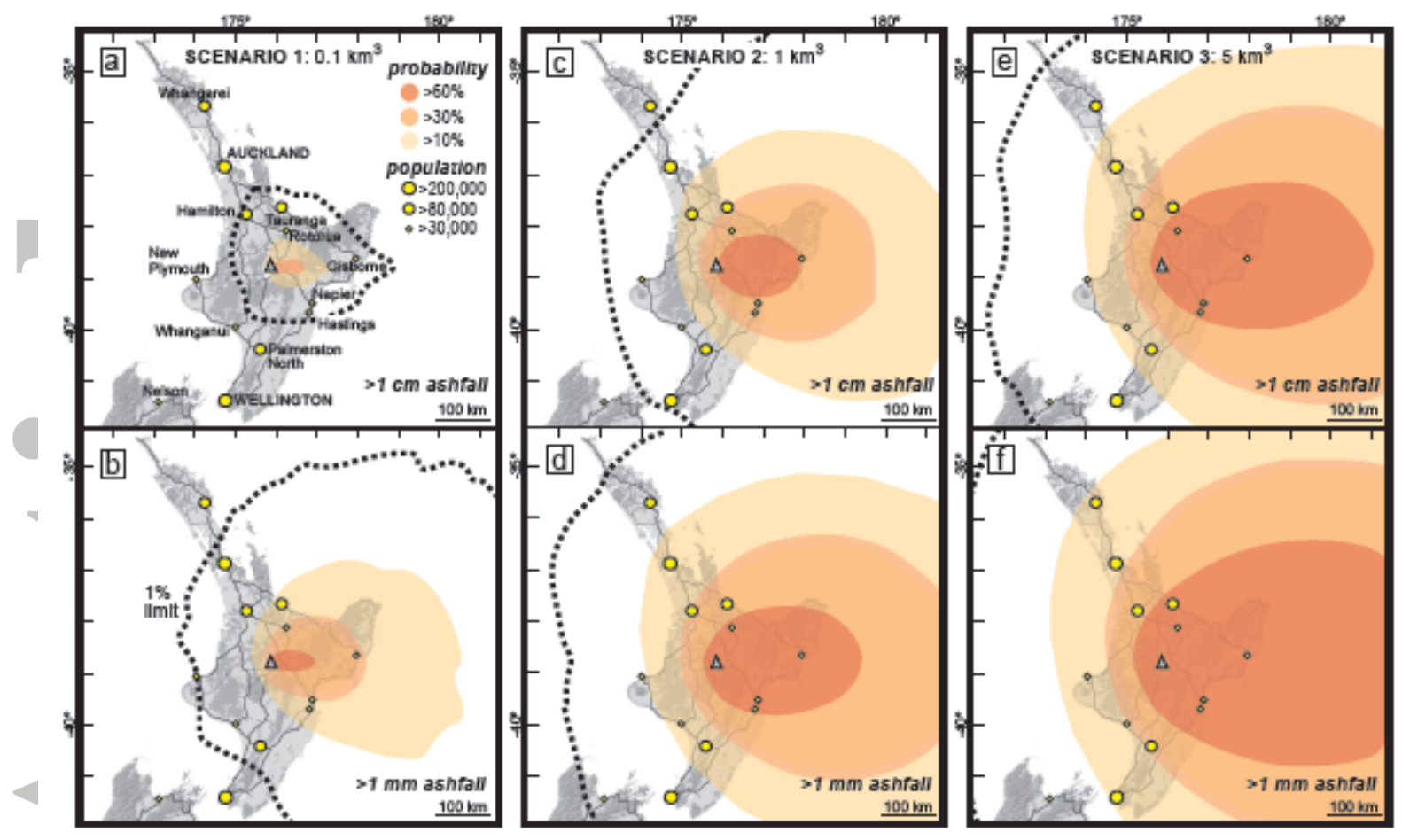

Figure 8. Probability maps produced from 1000 Ash3d model simulations showing probability contours of ash deposits across the North Island exceeding (a) $1 \mathrm{~cm}$ thickness and (b) $1 \mathrm{~mm}$ thickness for eruption Scenario $1\left(0.1 \mathrm{~km}^{3}\right)$, (c) $1 \mathrm{~cm}$ thickness and (d) $1 \mathrm{~mm}$ thickness for Scenario $2\left(1 \mathrm{~km}^{3}\right)$, (e) $1 \mathrm{~cm}$ thickness and (f) $1 \mathrm{~mm}$ thickness for Scenario 3 (5 $\mathrm{km}^{3}$ ). Locations of major population centers are labeled in (a) for reference. The black dashed line represents $1 \%$ limit where $99 \%$ of the simulations contained ash at the specified thickness within this boundary (see text for discussion). Background map in greyscale is from (C) 2018 Google Maps, with dark grey lines representing major highways and vent location indicated by grey triangle. 

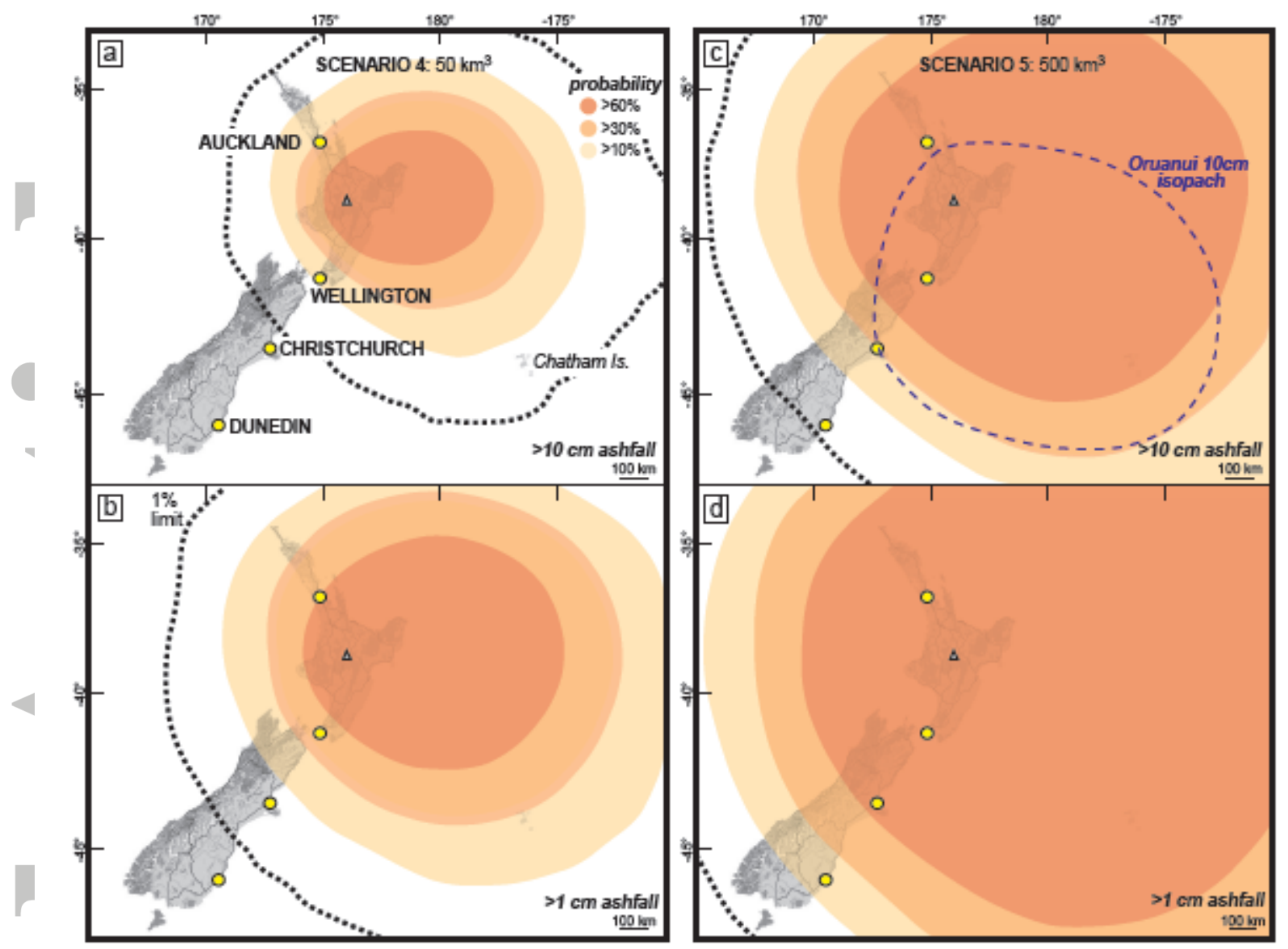

Figure 9. Probability maps produced from 1000 Ash3d model simulations showing probability contours of ash deposits across New Zealand exceeding (a) $10 \mathrm{~cm}$ thickness and (b) $1 \mathrm{~cm}$ thickness for eruption Scenario $4\left(50 \mathrm{~km}^{3}\right)$ and exceeding (c) $10 \mathrm{~cm}$ thickness and (d) $1 \mathrm{~cm}$ thickness for eruption Scenario $5\left(500 \mathrm{~km}^{3}\right)$. All other details as in Figure 8. Note the change in map scale and order of magnitude increase in deposit thicknesses when compared to Figure 8. 

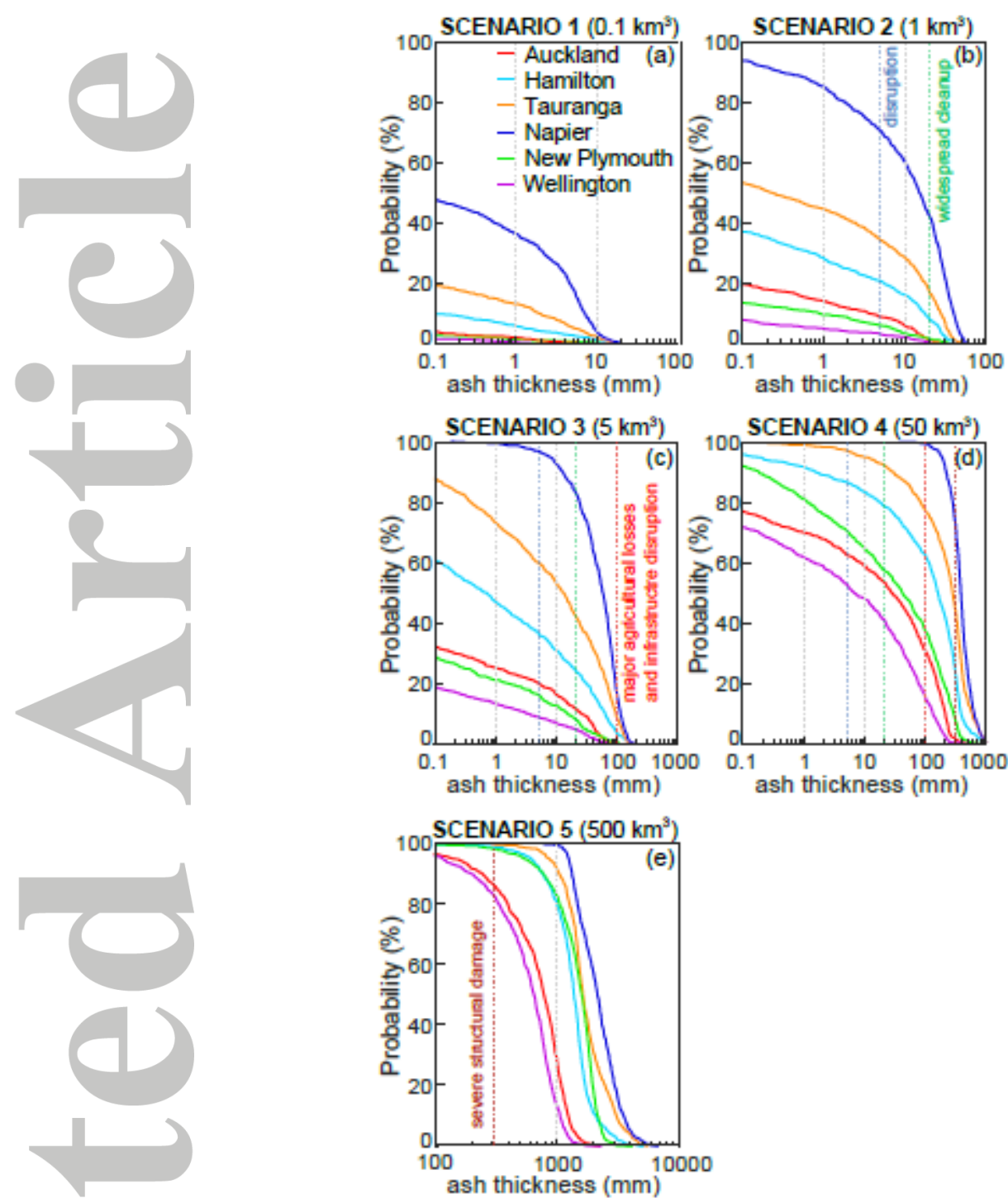

Figure 10. Probability-thickness plots produced from 1000 Ash3d model simulations showing the likelihood of ash at given thicknesses (on a log scale) for selected major population centers around the North Island for (a) Scenario $1\left(0.1 \mathrm{~km}^{3}\right)$, (b) Scenario $2\left(1 \mathrm{~km}^{3}\right)$, (c) Scenario $3\left(5 \mathrm{~km}^{3}\right)$, (d) Scenario $4\left(50 \mathrm{~km}^{3}\right)$ and (e) Scenario $5\left(500 \mathrm{~km}^{3}\right)$. Note the change in the thickness scale for (c) and (d) and again in (e) to account for larger eruptions. Dashed colored vertical lines represent major thickness thresholds that have been identified by risk and vulnerability studies (see Jenkins et al., 2015, and references therein). See text for discussion.

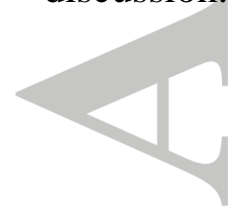



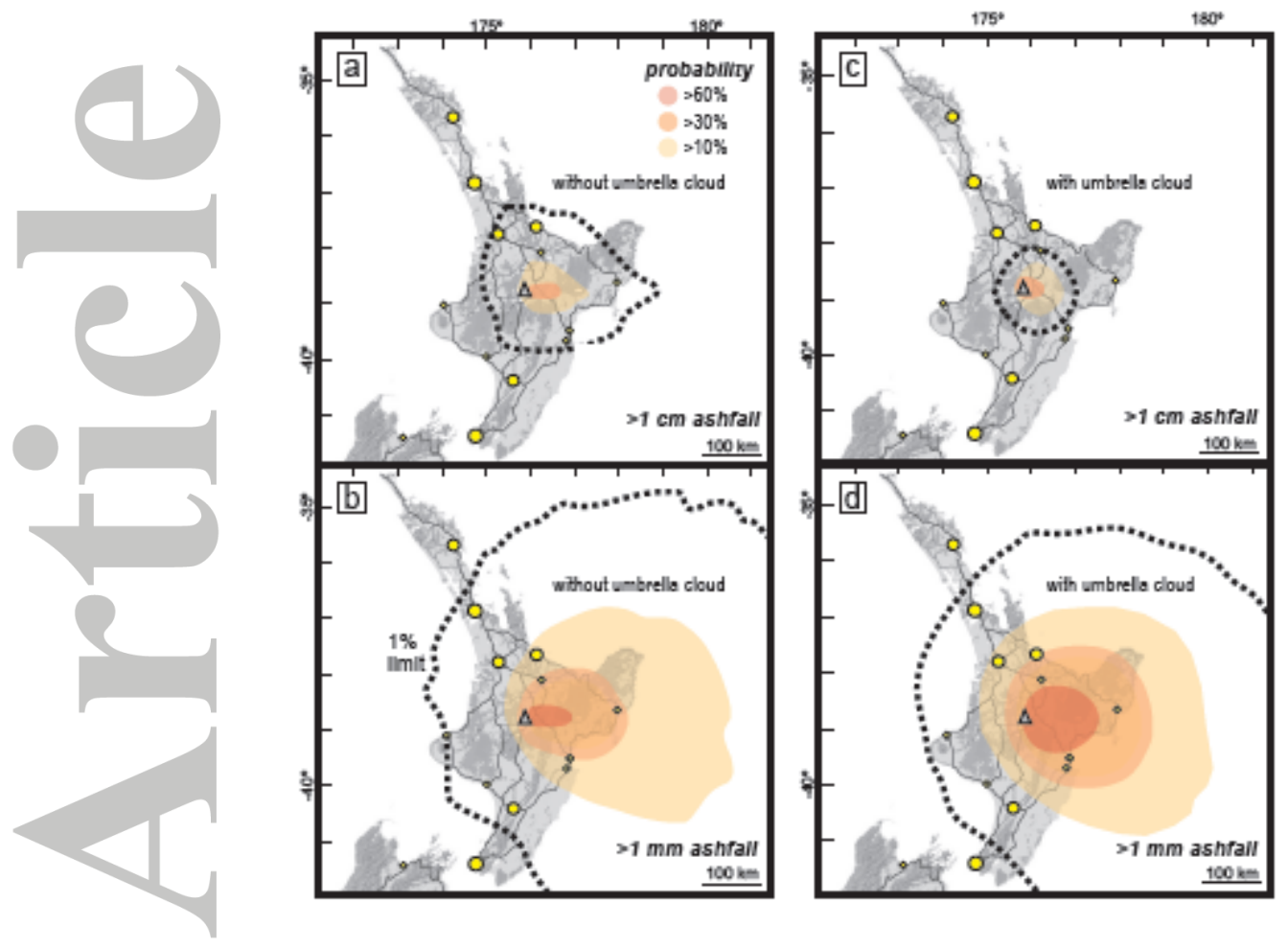

Figure 11. Probability maps produced from 1000 Ash3d model simulations showing probability contours of ash deposits across the North Island for eruption Scenario $1\left(0.1 \mathrm{~km}^{3}\right)$ without the umbrella cloud modification to Ash3d for (a) $1 \mathrm{~cm}$ thickness and (b) $1 \mathrm{~mm}$ thickness and with the umbrella cloud modification to Ash3d for (c) $1 \mathrm{~cm}$ thickness and (d) 1 mm thickness. Other details as in Figure 8. 

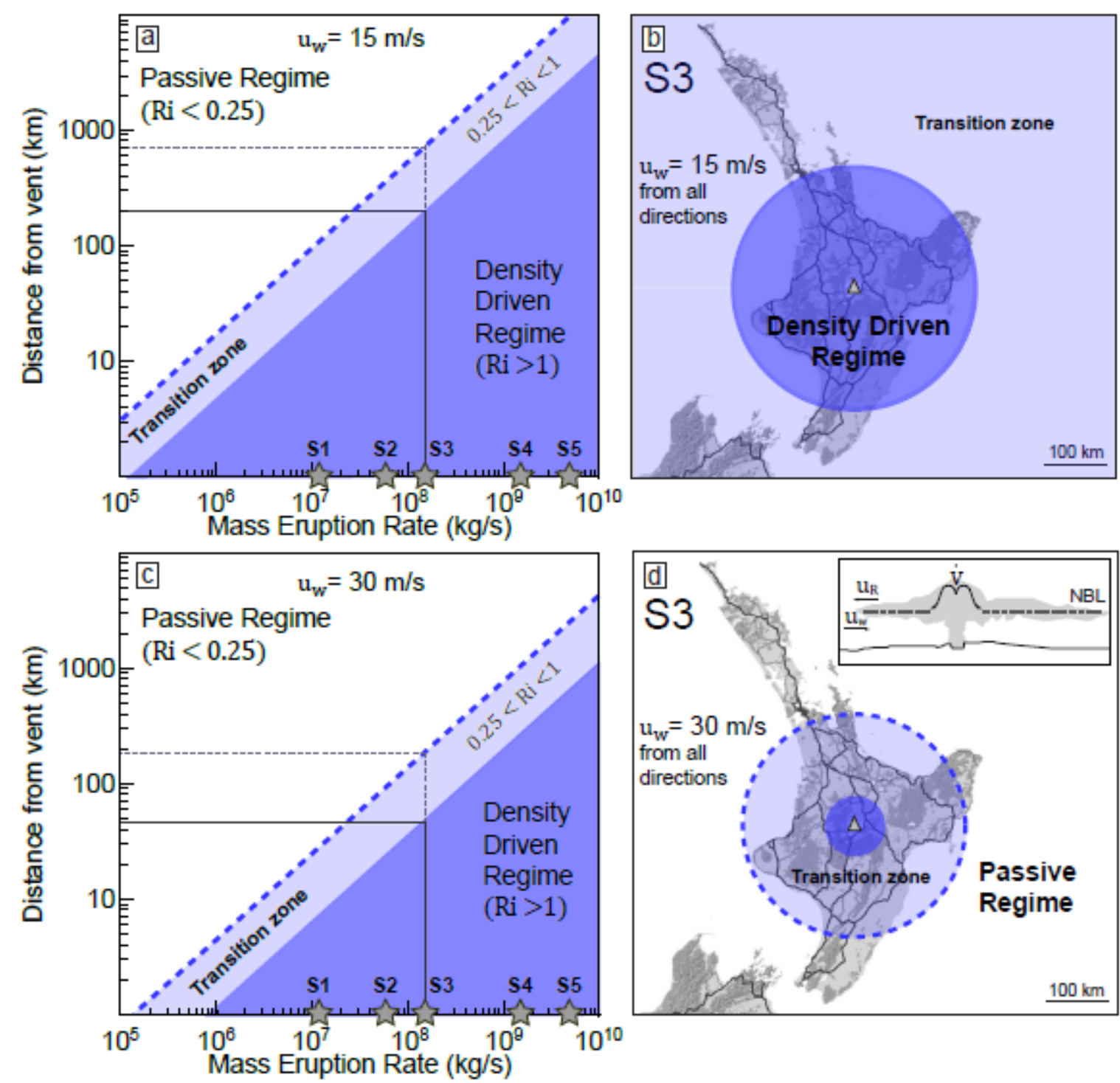

Figure 12. (a) Diagram highlighting the dominant transport mechanism of ash dispersal in the umbrella cloud as function of MER and distance from the source after Costa et al. (2013), obtained using equations (2), (6), and (7) assuming $u_{W}=15 \mathrm{~m} / \mathrm{s}, \lambda=0.2$, and $N=0.02$. Grey stars represent the position of the five eruptive scenarios from Taupo given their MER with the corresponding distance from vent shown for Scenario 3 where $R_{i}=1$ and $R_{i}=0.25$ for reference. (b) Map of the North Island showing the up-wind distance of transport mechanism shift calculated from (a) for a Scenario 3 eruption. Dark blue area represents the region where the density driven regime would occur $\left(R_{i}>1\right.$ ) (radius of $200 \mathrm{~km}$ from vent) and the light blue area represents the transitional zone $\left(0.25<R_{i}<1\right)$ assuming $u_{W}$ from all directions. (c)

The same diagram as in (a) but with double the wind speed where $u_{W}=30 \mathrm{~m} / \mathrm{s}$, with Scenario 3 again used as an example to show the corresponding distance from vent where the regime 
shift occurs under stronger winds. (d) Map of the North Island highlighting the significantly reduced area (radius of $<50 \mathrm{~km}$ from vent) of the density driven regime $\left(R_{i}>1\right)$ given higher stratospheric winds for Scenario 3 of $u_{W}=30 \mathrm{~m} / \mathrm{s}$. Inset schematic diagram of the plume shows the context of the terms $u_{W}$ and $u_{b}$ used in our calculations.
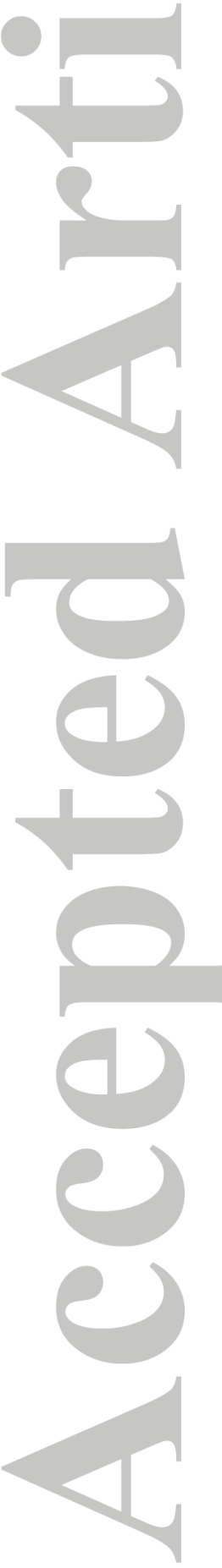

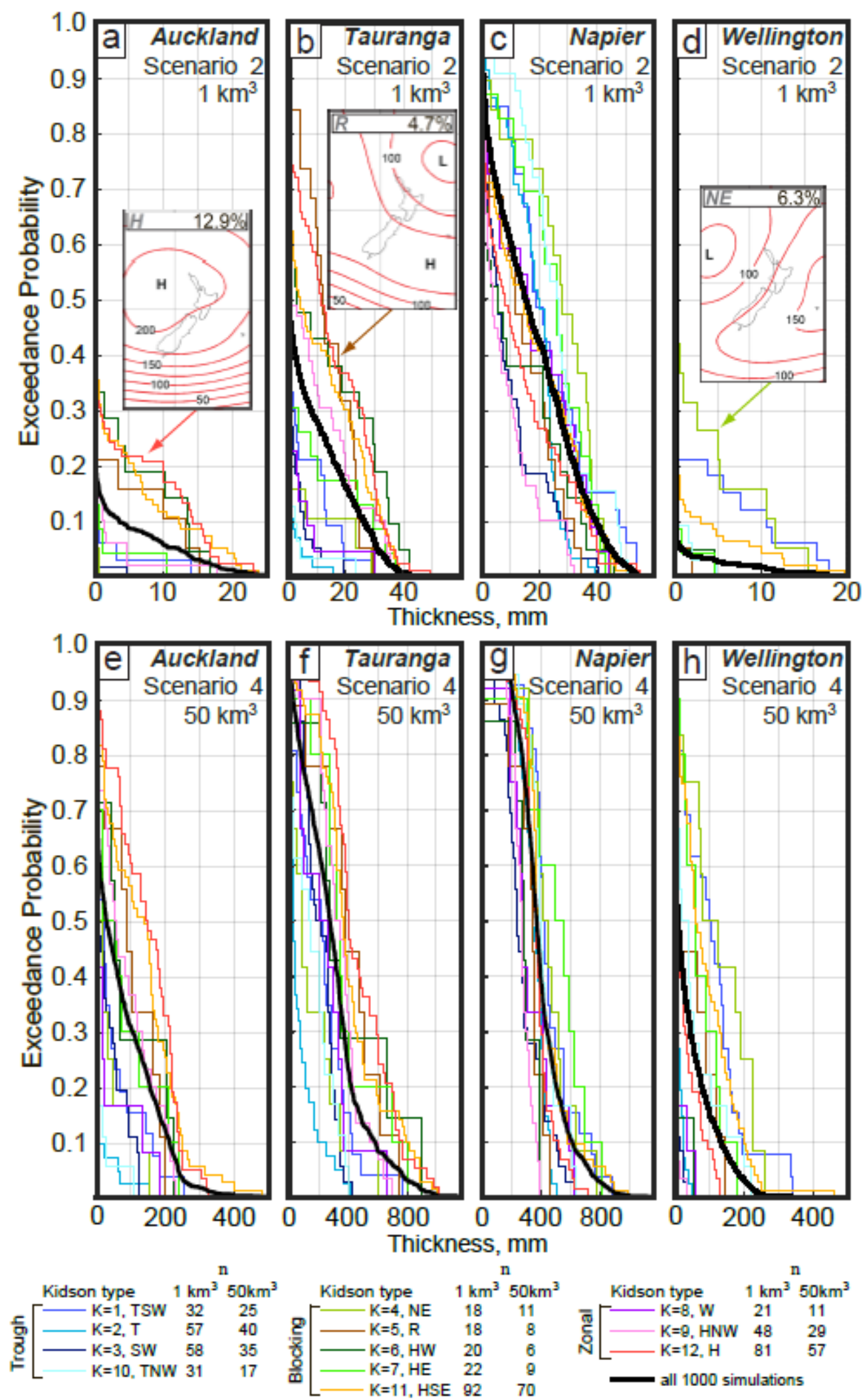

Figure 13. Exceedance probability-thickness plots produced from selected ashfall simulations that experienced only a single particular Kidson weather classification type for key population centers Auckland, Tauranga, Napier and Wellington for Scenario 2 eruptions (a-d) 
and Auckland, Tauranga, Napier and Wellington for Scenario 4 eruptions (e-h). The black line represents all 1000 simulations for reference and includes simulations with mixed multiple Kidson types. Lines for selected Kidson types missing in (a) and (d) means there were no simulations of that particular Kidson type that produced ashfall at those locations. See text for discussion and supporting information Figures S14 to S18 for examples of simulations that experienced only a single particular Kidson weather classification type.
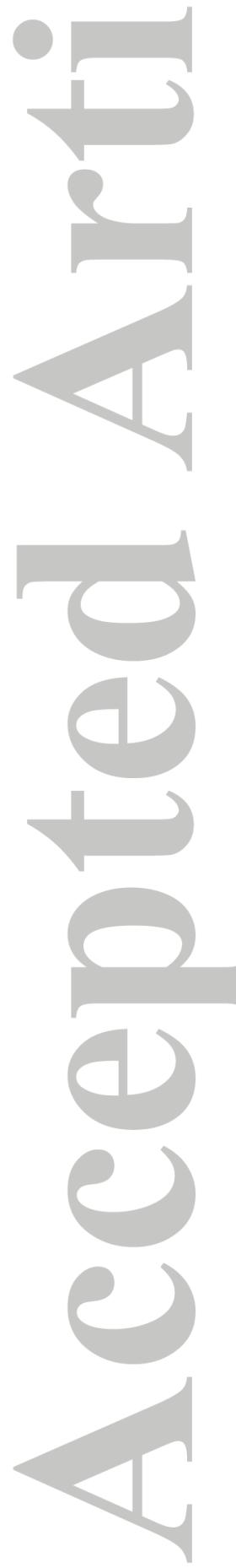

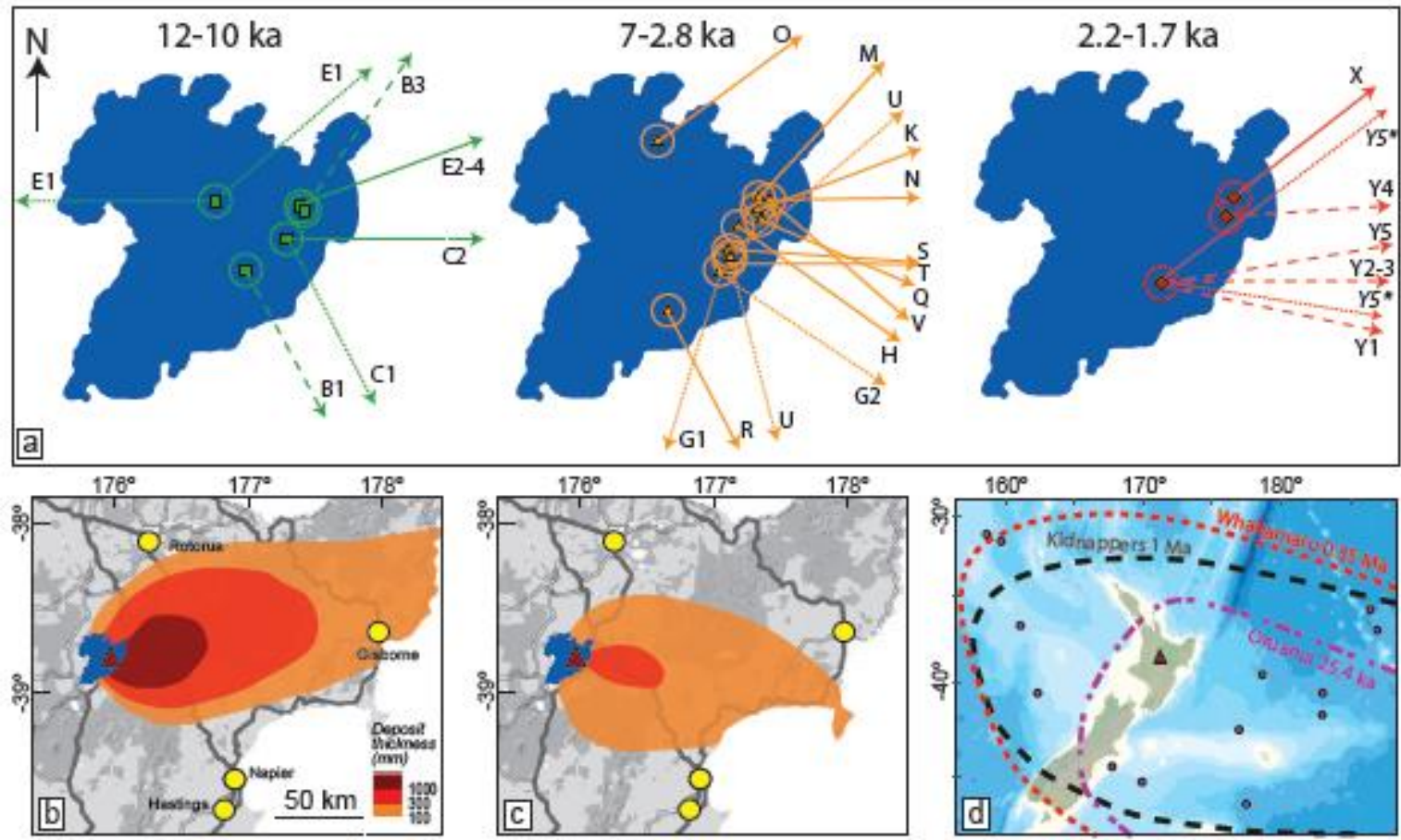

Figure 14. Examples of ash dispersal patterns from the geological record. (a) Ash dispersal directions from Holocene eruptions from Taupo volcano taken from the axis of isopach maps from Wilson (1993). The blue area is Lake Taupo. Letters refer to the eruptive units and subunits from Wilson (1993), with solid axis lines representing eruptions with isopach maps that show a single dispersal axis, dashed axis lines representing individual phases within single eruptions where isopach maps from subunits show a change in ash dispersal associated with a time break or change in vent site and dotted axis lines representing isopach maps that show bilobate distribution. For subunit Y5 a change in dispersal axis is inferred from changing wind directions after Houghton et al. (2014). (b) Isopach map from the total thickness of Unit Y (232 AD Taupo eruption) fall deposits after Wilson and Walker (1985). (c) Isopach map from the total thickness of Unit S (3.5 ka Waimihia eruption) fall deposits after Walker (1981b). (d) Dispersal patterns of TVZ supereruptions as determined from the distribution of tephras in DSDP and ODP cores (pink dots) after Carter et al. (2004).

Bathymetric map of the seafloor around New Zealand provided by NIWA under the NIWA Open Data License v1.0.

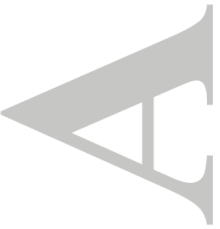


Table 1. Equations used to calculate the umbrella-cloud radius and velocity

\begin{tabular}{|c|c|c|}
\hline Number & Equation & Description \\
\hline 1 & $\frac{d Q_{m}}{d z_{v}}=Q_{m} \frac{k^{2}\left(1-\frac{z_{v}}{H}\right) \exp \left[k\left(\frac{Z_{v}}{H}-1\right)\right]}{H[1-(1+k) \exp (-k)]}$ & $\begin{array}{l}\text { Mass erupted per time step } Q_{m} \text { as a } \\
\text { function of the elevation } z_{v} \text { above the vent, } \\
\text { and the total plume height } H \text { above the } \\
\text { vent. } H=H_{u} \text { for simulations with an } \\
\text { umbrella cloud; } H=H_{T} \text { for simulations } \\
\text { without an umbrella cloud. The parameter } \\
k \text { is an adjustable factor. }\end{array}$ \\
\hline 2 & $R=\left(\frac{3 \lambda N \dot{V}}{2 \pi}\right)^{1 / 3} t^{2 / 3}$ & $\begin{array}{l}\text { Umbrella-cloud radius } R \text { versus time } t \text {, } \\
\text { where } \lambda \text { is an umbrella-cloud shape factor } \\
\text { taken to be } 0.2 \text { (Suzuki \& Koyaguchi, } \\
2009), N \text { is the Brunt-Väisälä frequency, } \dot{V} \\
\text { is the volume flux rate of air, gas, and } \\
\text { particles into the cloud (see below). }\end{array}$ \\
\hline 3 & $\dot{V}=C \sqrt{k_{e}} \frac{\dot{M}^{3 / 4}}{N^{5 / 8}}$ & $\begin{array}{l}\text { Volume rate of injection }(\dot{V}) \text { of air, gas, } \\
\text { and particles into the umbrella cloud, as a } \\
\text { function of mass eruption rate } \dot{M} \text {, Brunt- } \\
\text { Väisälä frequency } N \text {, and the radial } \\
\text { entrainment coefficient } k_{e} \text { of air into the } \\
\text { rising plume. The parameter } C \text { is an } \\
\text { empirical coefficient whose value is taken } \\
\text { as } 1 \times 10^{4} \mathrm{~m}^{3} \mathrm{~kg}^{-3 / 4} \mathrm{~s}^{-7 / 8} \text { in temperate } \\
\text { regions such as New Zealand (Suzuki and } \\
\text { Koyaguchi, 2009). This equation is } \\
\text { currently being revised to correct } \\
\text { inconsistencies. The revised equation is } \\
\text { expected to result in only minor change to } \\
R \text { (H.Webster, U.K. Met. Office, written } \\
\text { commun., 2019). }\end{array}$ \\
\hline 4 & $u_{r}=\frac{3}{4} u_{R} \frac{R}{r}\left(1+\frac{1}{3} \frac{r^{2}}{R^{2}}\right)$ & $\begin{array}{l}\text { Radial velocity } u_{r} \text { within the umbrella } \\
\text { cloud as a function of distance } r \text { from the } \\
\text { cloud center. } u_{R} \text { is the speed of the outer } \\
\text { edge of the umbrella cloud. From Costa et } \\
\text { al. }(2013) \text {. }\end{array}$ \\
\hline
\end{tabular}


Table 2. Summary of eruption scenarios and inputs used in Ash3d simulations

\begin{tabular}{|c|c|c|c|c|c|}
\hline Parameter(s) & Scenario 1 & Scenario 2 & Scenario 3 & Scenario 4 & Scenario 5 \\
\hline $\begin{array}{l}\text { Erupted volume, } \\
\mathrm{km}^{3} \text { DRE }\end{array}$ & 0.1 & 1 & 5 & 50 & 500 \\
\hline $\begin{array}{l}\text { Number of Holocene } \\
\text { eruptions of comparable } \\
\text { size (see Figure 2) }\end{array}$ & 11 & 6 & 2 & 1 & 0 \\
\hline $\begin{array}{l}\text { Annual probability from } \\
\text { Stirling and Wilson (2002) }\end{array}$ & $0.1 \%$ & $0.03 \%$ & $0.01 \%$ & $<0.01 \%$ & $<<0.01 \%$ \\
\hline $\begin{array}{l}\text { Plume or Umbrella Cloud } \\
\text { top height, km above sea } \\
\text { level }\end{array}$ & 15 & 15 & 20 & 20 & 20 \\
\hline Duration, hrs & 6 & 12 & 24 & 24 & 72 \\
\hline $\operatorname{MER}(\mathrm{kg} / \mathrm{s})$ & $1.16 \mathrm{E}+07$ & $5.79 \mathrm{E}+07$ & $1.45 \mathrm{E}+08$ & $1.45 \mathrm{E}+09$ & $4.82 \mathrm{E}+09$ \\
\hline Model domain & $\begin{array}{l}47.5-32.5^{\circ} \mathrm{S} \\
160-190^{\circ} \mathrm{E} \\
0-20 \mathrm{~km} \text { asl }\end{array}$ & $\begin{array}{l}47.5-32.5^{\circ} \mathrm{S} \\
160-190^{\circ} \mathrm{E} \\
0-20 \mathrm{~km} \text { asl }\end{array}$ & $\begin{array}{l}55-25^{\circ} \mathrm{S} \\
155-205^{\circ} \mathrm{E} \\
0-27 \mathrm{~km} \text { asl }\end{array}$ & $\begin{array}{l}55-25^{\circ} \mathrm{S} \\
155-205^{\circ} \mathrm{E} \\
0-27 \mathrm{~km} \text { asl }\end{array}$ & $\begin{array}{l}60-10^{\circ} \mathrm{S} \\
150-230^{\circ} \mathrm{E} \\
0-27 \mathrm{~km} \text { asl }\end{array}$ \\
\hline Nodal spacing & $\begin{array}{l}0.25^{\circ} \\
\text { horizontal } \\
2.0 \mathrm{~km} \\
\text { vertical }\end{array}$ & $\begin{array}{l}0.25^{\circ} \\
2.0 \mathrm{~km}\end{array}$ & $\begin{array}{l}0.35^{\circ} \\
2.0 \mathrm{~km}\end{array}$ & $\begin{array}{l}0.35^{\circ} \\
2.0 \mathrm{~km}\end{array}$ & $\begin{array}{l}0.35^{\circ} \\
2.0 \mathrm{~km}\end{array}$ \\
\hline Suzuki constant $k$ & 8 & 12 & 12 & 12 & 12 \\
\hline $\begin{array}{l}\text { Analogous eruptions of } \\
\text { broadly similar intensity }\end{array}$ & $\begin{array}{l}\text { Soufriere St } \\
\text { Vincent } \\
\text { 1902, } \\
\text { MSH } 1980 \\
\text { May, } \\
\text { Calbuco } \\
2015 \\
\text { upper VEI4 }\end{array}$ & $\begin{array}{l}\text { Redoubt } \\
2009 \text { event 5, } \\
\text { Hudson } 1991 \\
\text { (Chile) } \\
\text { VEI5 }\end{array}$ & $\begin{array}{l}\text { Pinatubo } \\
\text { 1991, } \\
\text { Quizapu } \\
\text { 1932, } \\
\text { Santa Maria } \\
\text { 1902, } \\
\text { Novarupta } \\
\text { 1912 VEI6 }\end{array}$ & $\begin{array}{l}\text { Taupo } \\
\text { 232AD, } \\
\text { Tambora. } \\
\text { Caldera } \\
\text { collapse } \\
\text { VEI7 }\end{array}$ & $\begin{array}{l}\text { Oruanui } 25.4 \mathrm{ka} \text {, } \\
\text { Bishop Tuff } \\
\text { Supereruption } \\
\text { VEI8 }\end{array}$ \\
\hline
\end{tabular}

Vent location set to $176.00^{\circ} \mathrm{E}, 38.817^{\circ} \mathrm{S}$ and diffusion coefficients $D_{x}, D_{y}$ and $D_{z}$ set to 0 for all scenarios. Validation tests (e.g. Mastin et al., 2016) have found that numerical diffusion inherent in Eulerian models like Ash3d spread ash sufficiently to reproduce well-mapped deposits. 
Table 3. Grain-size distribution used in all Ash3d runs for this study, based on the best-fit distribution determined by Mastin et al. (2016).

\begin{tabular}{|l|l|l|l|}
\hline $\begin{array}{l}\text { Diameter } \\
\mathrm{mm}\end{array}$ & $\begin{array}{l}\text { Mass } \\
\text { fraction }\end{array}$ & $\begin{array}{l}\text { Density } \\
\mathrm{kg} \mathrm{m}^{-3}\end{array}$ & $\begin{array}{l}\text { Shape } \\
\text { factor } F\end{array}$ \\
\hline 2.000 & 0.0208 & 800 & 0.44 \\
\hline 1.414 & 0.0084 & 1000 & 0.44 \\
\hline 1.000 & 0.0141 & 1200 & 0.44 \\
\hline 0.707 & 0.0214 & 1400 & 0.44 \\
\hline 0.5 & 0.0459 & 1600 & 0.44 \\
\hline 0.354 & 0.0723 & 1800 & 0.44 \\
\hline 0.25 & 0.0532 & 2000 & 0.44 \\
\hline 0.1768 & 0.0219 & 2200 & 0.44 \\
\hline 0.125 & 0.0165 & 2400 & 0.44 \\
\hline 0.088 & 0.0115 & 2600 & 0.44 \\
\hline 0.2176 & 0.0428 & 600 & 1 \\
\hline 0.2031 & 0.1714 & 600 & 1 \\
\hline 0.1895 & 0.2856 & 600 & 1 \\
\hline 0.1768 & 0.1714 & 600 & 1 \\
\hline 0.1649 & 0.0428 & 600 & 1 \\
\hline & & & \\
\hline
\end{tabular}

$F \equiv(b+c) / 2 a$, where $a, b$, and $c$, are the semi-major, intermediate, and semi-minor radii of a 3-D ellipsoid (from Wilson and Huang, 1979). Italicized size fractions refer to ash aggregates. 
Table 4. Average arrival times of ashfall at selected major centers around the North Island of New Zealand, ordered from North to South.

\begin{tabular}{|l|c|c|c|c|c|c|c|c|c|c|}
\hline Scenario & \multicolumn{2}{|c|}{1} & \multicolumn{2}{c|}{2} & \multicolumn{2}{c|}{3} & \multicolumn{2}{c|}{4} & \multicolumn{2}{c|}{5} \\
\hline Size & $0.1 \mathrm{~km}^{3}($ no umbrella) & \multicolumn{2}{|c|}{$1 \mathrm{~km}^{3}$} & \multicolumn{2}{|c|}{$5 \mathrm{~km}^{3}$} & \multicolumn{2}{|c|}{$50 \mathrm{~km}^{3}$} & \multicolumn{2}{|c|}{$500 \mathrm{~km}^{3}$} \\
\hline City & mean (hrs) & $\sigma$ & mean & $\sigma$ & mean & $\sigma$ & mean & $\sigma$ & mean & $\sigma$ \\
\hline Auckland & 8.4 & 2.6 & 9.1 & 3.8 & 13.9 & 7.8 & 11.1 & 7.4 & 8.5 & 9.0 \\
\hline Hamilton & 6.1 & 2.4 & 7.1 & 4.0 & 10.2 & 7.4 & 5.4 & 5.4 & 2.1 & 2.0 \\
\hline Tauranga & 5.2 & 2.9 & 5.4 & 3.7 & 6.1 & 5.9 & 2.3 & 2.8 & 1.2 & 0.5 \\
\hline New Plymouth & 7.7 & 2.9 & 9.5 & 4.0 & 15.8 & 7.8 & 10.4 & 7.0 & 3.9 & 3.1 \\
\hline Napier & 3.5 & 2.5 & 3.5 & 3.0 & 3.0 & 3.0 & 1.2 & 0.5 & 0.9 & 0.1 \\
\hline Wellington & 10.7 & 2.5 & 11.1 & 4.1 & 15.7 & 7.1 & 13.9 & 7.4 & 11.5 & 10.4 \\
\hline
\end{tabular}

